\title{
Cyclopropenation and Related Reactions of Ruthenium Vinylidene Complexes
}

\section{Pei-Chen Ting, Ying-Chih Lin,* Gene-Hsiang Lee, Ming-Chu Cheng, and Yu Wang}

Contribution from the Department of Chemistry, National Taiwan University, Taipei, Taiwan 106, Republic of China

Received January 2, $1996^{\otimes}$

\begin{abstract}
Facile deprotonation of a number of cationic ruthenium vinylidene complexes, followed by cyclopropenation, is accomplished in acetone. The deprotonation of $[\mathrm{Ru}]=\mathrm{C}=(\mathrm{Ph}) \mathrm{CH}_{2} \mathrm{R}^{+}$, $\left([\mathrm{Ru}]=\left(\eta^{5}-\mathrm{C}_{5} \mathrm{H}_{5}\right)\left(\mathrm{PPh}_{3}\right)_{2} \mathrm{Ru}\right)$ by $n^{-} \mathrm{Bu}_{4}$ $\mathrm{NOH}$ induces a novel cyclization reaction and yields the neutral cyclopropenyl complexes $[\mathrm{Ru}]-\mathrm{C}=\mathrm{C}(\mathrm{Ph}) \mathrm{CHR}$ (3b, $\left.\mathrm{R}=\mathrm{CN} ; \mathbf{3 c}, \mathrm{R}=\mathrm{Ph} ; \mathbf{3 d}, \mathrm{R}=\mathrm{CH}=\mathrm{CH}_{2} ; \mathbf{3 e}, \mathrm{R}=\mathrm{CH}=\mathrm{CMe}_{2}\right)$. Complex $[\mathrm{Ru}]-\mathrm{C}=\mathrm{C}\left(\mathrm{C}_{6} \mathrm{H}_{9}\right) \mathrm{CHCN}^{+}(\mathbf{3 k})$ is similarly prepared. Protonation of $\mathbf{3 b}-\mathbf{3 e}$ regenerates the corresponding vinylidene complexes. Deprotonation of $[\mathrm{Ru}]=\mathrm{C}=\mathrm{C}(\mathrm{Ph}) \mathrm{CH}_{2} \mathrm{COOMe}^{+}(\mathbf{2 h})$ by $n-\mathrm{Bu}_{4} \mathrm{NOH}$ induces a different type of cyclization and yields the neutral furan complex $[\mathrm{Ru}]-\mathrm{C}=\mathrm{C}(\mathrm{Ph}) \mathrm{CH}=\mathrm{C}(\mathrm{O}) \mathrm{OMe}(\mathbf{4 h})$. The cyclopropenyl complex containing a methoxy substituent cannot be prepared from $[\mathrm{Ru}]=\mathrm{C}=\mathrm{C}(\mathrm{Ph}) \mathrm{CH}_{2} \mathrm{OCH}_{3}{ }^{+}(\mathbf{2 i})$, but $\mathrm{F}^{-}$of $n-\mathrm{Bu}_{4} \mathrm{NF}$ attacks the $\mathrm{C}_{\alpha}$ of $2 \mathbf{i}$ to produce the unstable vinyl complex $[\mathrm{Ru}] \mathrm{C}(\mathrm{F})=\mathrm{C}(\mathrm{Ph}) \mathrm{CH}_{2} \mathrm{OCH}_{3}(\mathbf{5})$. Complex $[\mathrm{Ru}]-\mathrm{C}=\mathrm{C}(\mathrm{Ph}) \mathrm{C}(\mathrm{CN}) \mathrm{OCH}_{3}(\mathbf{9 b})$ was indirectly prepared from the addition of TCNQ to $\mathbf{3 b}$, giving $[\mathrm{Ru}]=\mathrm{C}=\mathrm{C}(\mathrm{Ph}) \mathrm{CH}(\mathrm{CN}) \mathrm{TCNQ}(\mathbf{6 b})$ followed by methanolysis. Unlike $\mathbf{3}$, complex $9 \mathbf{b}$ is not converted to vinylidene complex, instead, removal of the methoxy substituent by acid gives the

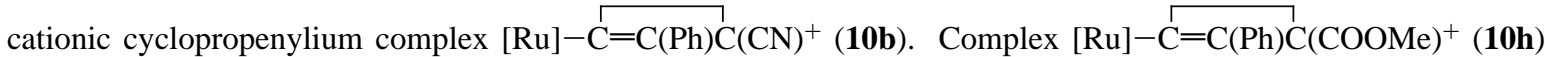
is similarly prepared from $\mathbf{4 h}$ via a TCNQ complex $\mathbf{6 h}$ followed by a methoxy-substituted complex $\mathbf{9 h}$. In the presence of allyl iodide, opening of the three-membered ring of $\mathbf{3 b}$, followed by a subsequent oxidative coupling reaction, gives a dimeric dicationic product $\{[\mathrm{Ru}]=\mathrm{C}=\mathrm{C}(\mathrm{Ph})-\mathrm{CHCN}\}_{2}{ }^{2+}(\mathbf{1 1})$. Proton abstraction of 11 by $n-\mathrm{Bu}_{4-}$

$\mathrm{NF}$ gives the biscyclopropenyl complex $\{[\mathrm{Ru}]-\mathrm{C}=\mathrm{C}(\mathrm{Ph}) \mathrm{CCN}\}_{2}(\mathbf{1 2})$. Molecular structures of complexes $\mathbf{3 b}, \mathbf{3 f}$, 4h, 6b, 9b, and 11 have been confirmed by X-ray diffraction analysis.
\end{abstract}

\section{Introduction}

Cyclopropene is believed to be the most highly strained cycloalkene, with the estimated substantial strain energy of more than $50 \mathrm{kcal} / \mathrm{mol}^{1}{ }^{1}$ This molecule has hence been under intense investigation $^{2}$ and has played a crucial role in the development of important concepts such as aromaticity and chemical reactivities. $^{3}$ Three general methods are known for the synthesis of cyclopropenes: ${ }^{4}$ viz., addition of carbene to alkyne, ${ }^{5}$ ring closure of vinylcarbene, ${ }^{6}$ and 1,2-elimination of a suitable precursor such as halocyclopropane. ${ }^{7}$ Two recent papers ${ }^{2 a, b}$ have suggested vinylidene (alkylidenecarbene) to be the intermediate in the thermal rearrangement of cyclopropene: i.e. when substituted cyclopropenes are heated or irradiated, complex

${ }^{\otimes}$ Abstract published in Advance ACS Abstracts, June 15, 1996.

(1) (a) Liebman, J. F.; Greenberg, A. Strained Organic Molecules; Wiley: New York, 1978; p 91. (b) Special issue on strained organic compounds: Chem. Rev. 1989, 89.

(2) (a) Maier, G.; Preiss, T.; Reisenauer, H. P.; Hess, B. A., Jr.; Schaad, L. J. J. Am. Chem. Soc. 1994, 116, 2014. (b) Hopf, H.; Plagens, A.; Walsh, R. J. Chem. Soc., Chem. Commun. 1994, 1467. (c) Maier, G.; Reisenauer, H. P.; Pacl, H. Angew. Chem., Int. Ed. Engl. 1994, 33, 1248.

(3) (a) Liebman, J. F.; Greenberg, A. Chem. Rev. 1976, 76, 311. (b) Halton, B.; Banwell, M. G. In The Chemistry of the Cyclopropyl Group. Part 2; Patai, S., Rappoport, Z., Eds.; Wiley: Chichester, 1987; Chapter 21, p 1223.

(4) Billups, W. E.; McCord, D. J. Angew. Chem., Int. Ed. Engl. 1994, $33,1332$.

(5) (a) Maier, G.; Hoppe, M.; Reisenauer, H. P.; Krüger, C. Angew. Chem., Int. Ed. Engl. 1982, 21, 437. (b) Dowd, P.; Garner, P.; Schappert, R.; Irngartinger, H.; Goldmann, A. J. Org. Chem. 1982, 47, 4240. (c) Suvorova, G. N.; Komendantov, M. I. Zh. Org. Khim. 1982, 18, 1882; Chem. Abstr. 1983, 98, 71511. (c) Doyle, M. P; Protopopova, M.; Muller, P.; Ene, D.; Shapiro, E. A. J. Am. Chem. Soc. 1994, 116, 8492. mixtures of 1,3-dienes, allenes, and acetylenes are formed. ${ }^{8}$ This strongly suggests that the formation of acetylenes involves vinylidenes as intermediates. ${ }^{9}$ Some theoretical results also suggest that the acetylenic products are formed from vinylidene produced through bond breaking and hydrogen shift. ${ }^{10,11}$ It thus appears that vinylidene is an important intermediate in the thermal rearrangement of cyclopropene to acetylene. ${ }^{12}$ However, organic vinylidene $\left(\mathrm{R}_{2} \mathrm{C}=\mathrm{C}\right.$ : $)$ is thermodynamically unstable and evidence for its existence has been derived mostly from the reaction products. Fortunately, vinylidene, among a variety of reactive organic species that can be stabilized by complex formation with transition metals, has been shown to form a plethora of stable organometallic compounds. Particu-

(6) (a) Baldwin, J. E.; Black, K. A. J. Am. Chem. Soc. 1984, 106, 1029. (b) Ando, W.; Hanyu, Y.; Takata, T.; Ueno, K. J. Am. Chem. Soc. 1984 106, 2216. (c) Dürr, H.; Klauck, G.; Peters, K.; von Schnering, H. G. Angew. Chem., Int. Ed. Engl. 1983, 22, 332. (d) Kett, M. W.; Johnson, R. P. Tetrahedron. Lett. 1983, 24, 2523. (e) Franck-Neumann, M.; Miesch, M. Tetrahedron. Lett. 1984, 25, 2909.

(7) (a) Baird, M. S.; Buxton, S. R.; Whitley, J. S. Tetrahedron. Lett. 1983, 24, 1509. (b) Padwa, A.; Pulwer, M. J.; Rosenthal, R. J. J. Org. Chem. 1984, 49, 856. (c) Harnisch, J.; Baumgartel, O.; Szeimies, G.; Meerssche, M. V.; Germain, G.; Declercq, J.-P. J. Am. Chem. Soc. 1979, 101,3370 .

(8) Gajewski, J. J. Hydrocarbon Thermal Isomerizations; Wiley: New York, 1981; pp 22-25.

(9) Walsh, R.; Wolf, C.; Untiedt, S.; de Meijere, A. J. Chem. Soc., Chem. Commun. 1992, 421.

(10) Yoshimine, M.; Pacansky, J.; Honjou, N. J. Am. Chem. Soc. 1989, $111,2785,4198$.

(11) Stng, P. J. In Carbene(oide); Regitz, M., Ed.; Georg Thieme: Stuttgart, 1989; p 84ff.

(12) Likhotvorik, I. R.; Brown, D. W.; Jones, M., Jr. J. Am. Chem. Soc. 1994, 116,6175 . 
larly the mononuclear ruthenium(II) moieties, $\mathrm{CpRu}\left(\mathrm{PR}_{3}\right)_{2}{ }^{+}(\mathrm{Cp}$ $=\eta^{5}-\mathrm{C}_{5} \mathrm{H}_{5}$ ), play an important role in the stabilization of $[\mathrm{Ru}]=\mathrm{C}=\mathrm{CRR}^{\prime}$ derivatives.

Metal vinylidene complexes have also attracted a great deal of attention since they offer the possibility of development of new types of organometallic intermediates that may have unusual reactivity. Extensive reviews on this subject have appeared recently. ${ }^{13}$ The best entry into the transition metal vinylidene complexes is the addition of electrophiles to the electron-rich carbon of metal alkynyl complexes. ${ }^{14}$ A theoretical study of the vinylidene complex has revealed the localization of electron density on $\mathrm{C}_{\beta}$ (HOMO) or the $\mathrm{M}=\mathrm{C}$ double bond and electron deficiency at $\mathrm{C}_{\alpha} \cdot{ }^{15}$ Thus the $\mathrm{M}=\mathrm{C}$ double bond and the $\mathrm{C}_{\beta}$ atom are more susceptible to electrophilic attack whereas the $\mathrm{C}_{\alpha}$ atom is prone to nucleophilic attack. ${ }^{16}$ Hence the reactions of such compounds containing electron-rich metals with electrophiles lead to formation of carbene complexes. ${ }^{17}$ On the other hand, their reactions with nucleophiles generally result in the formation of vinyl derivatives. Protonation of vinylidene ligand at $\mathrm{C}_{\beta}$ is known to readily form a carbyne unless the ligand is present in a cationic form. With a more electron rich metal center, addition to the $\mathrm{M}=\mathrm{C}$ bond yields an $\eta^{2}$-allene- or heteroketene-metal complex. ${ }^{18,19}$ Addition of the acetylenic alcohols $\mathrm{HC} \equiv \mathrm{C}\left(\mathrm{CH}_{2}\right)_{n} \mathrm{OH}$ to $\mathrm{CpRuL}_{2} \mathrm{Cl}$ also affords cyclic carbene complexes. The reaction proceeds via initial formation of the vinylidene complexes, followed by an intramolecular attack of the terminal alcohol function on $\mathrm{C}_{\alpha}{ }^{20}$ A study of the reaction of alcohols with $\mathrm{Ru}$ vinylidene complexes has shown that the electron-withdrawing groups on the acetylide unit or on the metal facilitate nucleophilic attack at $\mathrm{C}_{\alpha \cdot}{ }^{21}$

(13) (a) Bruce, M. R. Chem. Rev. 1991, 91, 197. (b) Bruce, M. I.; Swincer, A. G. Adv. Organomet. Chem. 1983, 22, 59. (c) Davies, S. G.; McNally, J. P.; Smallridge, A. J. Adv. Organomet. Chem. 1990, $30,1$.

(14) (a) Werner, H. Angew. Chem., Int. Ed. Engl. 1990, 29, 1077. (b) Werner, H.; Rappert, T.; Wolf, J. Isr. J. Chem. 1990, 30, 377. (c) Werner, H.; Hohn, A.; Schulz, M. J. Chem. Soc., Dalton Trans. 1991, 777. (d) Schafer, M.; Wolf, J.; Werner, H. J. Chem. Soc., Chem. Commun. 1991, 1341. (e) Schneider, D.; Werner, H. Angew. Chem. 1991, 103, 710. (f) Werner, H.; Dirnberger, T.; Hohn, A. Chem. Ber. 1991, 124, 1957. (g) Werner, H.; Weinhand, R.; Knaup, W. Organometallics 1991, 10, 3967. (h) Rappert, T. O.; Mahr, N.; Wolf, J.; Werner, H. Organometallics 1992, 11, 4156. (i) Nakanishi, S.; Goda, K.; Uchiyama, S.; Otsuji, Y. Bull. Chem. Soc. Jpn. 1992, 65, 2560. (j) Haquette, P.; Pirio, N.; Touchard, D.; Toupet, L.; Dixneuf, P. H. J. Chem. Soc., Chem. Commun. 1993, 163. (k) Watatuski, Y.; Koga, N.; Yamazaki, H.; Morokuma, K. J. Am. Chem. Soc. 1994, 116, 8105.

(15) (a) Kostic, N. M.; Fenske, R. F. Organometallics 1982, 1, 974. (b) Werner, H.; Wolf, J.; Muller, G.; Krüger, C. Angew. Chem., Int. Ed. Engl. 1984, 28, 431 .

(16) (a) Espuelas, J.; Esteruelas, M. A.; Lahoz, F. J.; Oro, L. A.; Valero, C. Organometallics 1993, 12, 663. (b) Werner, H.; Meyer, U.; Esteruelas, M. A.; Sola, E.; Oro, L. A.; Valero, C. J. Organomet. Chem. 1989, 366, 187. (c) Andriollo, A.; Esteruels, M. A.; Meyer, U.; Oro, L. A.; SanchezDelgardo, R. A.; Sola, E.; Velcro, C.; Werner, H. J. Am. Chem. Soc. 1989, 111, 7431. (d) Espuelas, J.; Esteruelas, M. A.; Lahoz, F. J.; Oro, L. A.; Ruiz, N. J. Am. Chem. Soc. 1993, 115, 4683.

(17) (a) Davison, A.; Selegue, J. P. J. Am. Chem. Soc. 1978, 100, 7763. (b) Davison, A.; Selegue, J. P. J. Am. Chem. Soc. 1980, 102, 2455. (c) Casey, C. P.; Miles, W. H.; Tukoda, H.; O’Connor, J. M. J. Am. Chem. Soc. 1982, 104, 3761. (d) Kremer, K. A. M.; Kuo, G.; O’Connor, E. I.; Helquist, P.; Kerber, R. C. J. Am. Chem. Soc. 1982, 104, 6119. (e) Bodner, G. S.; Smith, D. E.; Hatton, W. G.; Heah, P. C.; Georgiou, S.; Rheingold, A. L.; Geib, S. J.; Hutchinson, J. P.; Gladysz, J. A. J. Am. Chem. Soc. 1987, 109, 7688.

(18) (a) Werner, H; Wolf, J.; Zolk, R.; Schubert, U. Angew. Chem., Int. Ed. Engl. 1983, 22, 981. (b) Wolf, J.; Zolk, R.; Schubert, U.; Werner, H. J. Organomet. Chem. 1988, 340, 161 .

(19) (a) Hoel, E. L.; Ansell, G. B.; Leta, S. Organometallics 1984, 3, 1633. (b) Consiglio, G.; Schwab, R.; Morandini, F. J. Chem. Soc., Chem. Commun. 1988, 25.

(20) Bruce, M. I.; Swincer, A. G.; Thomson, B. J.; Wallis, R. C. Aust. J. Chem. 1980, 33, 2605.

(21) Bruce, M. I.; Swincer, A. G. Aust. J. Chem. 1980, 33, 1471.
Most surprisingly, with such a background, the relation between vinylidene and cyclopropene in the organometallic system has been mostly left unnoticed. We believed that electron-withdrawing functionality, such as the $\mathrm{CN}$ group, at $\mathrm{C}_{\gamma}$ might play a role in enhancing the acidity of its neighboring proton. Thus an intramolecular cycloaddition leading to the formation of the cyclopropenyl complex may be effected by a base. We have reported our preliminary results on one specific compound in a recent communication. ${ }^{22}$ After thorough exploration, it has been observed that the method indeed leads to a number of cyclopropenyl complexes. Utilizing the abovementioned reactivities, herein we report the unprecedented cyclopropenation reaction of the vinylidene ligands with various substituents at $\mathrm{C}_{\gamma}$ and limitations of this type of reaction. In addition, a coupling reaction of the cyclopropenyl complex leading to the synthesis of the first 2,2'-bicyclopropenyl metal complex is also reported.

\section{Results and Discussion}

Metal Vinylidene Complexes. Treatment of $[\mathrm{Ru}]-\mathrm{C} \equiv \mathrm{C}-$ $\mathrm{Ph}$ (1a) with $\mathrm{ICH}_{2} \mathrm{CN}$ affords the cationic vinylidene complex $[\mathrm{Ru}]=\mathrm{C}=\mathrm{C}(\mathrm{Ph}) \mathrm{CH}_{2} \mathrm{CN}^{+}$(2b) with $72 \%$ yield. Similarly, preparations of complexes $[\mathrm{Ru}]=\mathrm{C}=\mathrm{C}(\mathrm{Ph}) \mathrm{CH}_{2} \mathrm{R}^{+}(\mathbf{2} \mathbf{a}, \mathrm{R}=\mathrm{H}$; 2c, $\mathrm{R}=\mathrm{Ph} ; \mathbf{2 d}, \mathrm{R}=\mathrm{CH}=\mathrm{CH}_{2} ; \mathbf{2 e}, \mathrm{R}=\mathrm{CH}=\mathrm{CMe}_{2} ; \mathbf{2 h}, \mathrm{R}=$ $\left.\mathrm{COOCH}_{3} ; \mathbf{2} \mathbf{i}, \mathrm{R}=\mathrm{COOC}_{2} \mathrm{H}_{5} ; \mathbf{2} \mathbf{j}, \mathrm{R}=\mathrm{OCH}_{3}\right)$ have all been achieved with high yields. The complex $[\mathrm{Ru}]=\mathrm{C}=\mathrm{C}\left(\mathrm{C}_{6} \mathrm{H}_{9}\right) \mathrm{CH}_{2}-$ $\mathrm{CN}^{+}\left(\mathbf{2} \mathbf{k}, \mathrm{C}_{6} \mathrm{H}_{9}=1\right.$-cyclohexenyl) is also prepared from the reaction of $[\mathrm{Ru}]-\mathrm{C} \equiv \mathrm{C}-\mathrm{C}_{6} \mathrm{H}_{9}$ with $\mathrm{ICH}_{2} \mathrm{CN}$. With the exceptions of $\mathbf{2} \mathbf{h}$ and $\mathbf{2} \mathbf{i}$, the vinylidene complexes mentioned above have been prepared in $\mathrm{CH}_{2} \mathrm{Cl}_{2}$ either at room temperature or at refluxing temperature. For the synthesis of $\mathbf{2} \mathbf{h}$ and $\mathbf{2} \mathbf{i}$, a mixture of $\mathrm{CH}_{2} \mathrm{Cl}_{2} / \mathrm{CHCl}_{3}(1: 1 \mathrm{v} / \mathrm{v})$ was used as solvent due to the necessity of achieving higher reaction temperature. The most characteristic spectroscopic data of these vinylidene complexes consist of strongly deshielded $\mathrm{C}_{\alpha}$ resonance as a triplet at $\delta$ $340 \pm 5$ in the ${ }^{13} \mathrm{C}$ NMR spectrum and a single ${ }^{31} \mathrm{P}$ NMR resonance normally at around $\delta 42 \pm 1$ in $\mathrm{CDCl}_{3}$ at room temperature, which is due to the fluxional behavior of the vinylidene ligand. ${ }^{23}$

Deprotonation/Cyclopropenation of Vinylidene Complexes. Deprotonation of $\mathbf{2 b}$ by $n-\mathrm{Bu}_{4} \mathrm{NOH}$ induces a new cyclization reaction and yields a neutral cyclopropenyl complex

$[\mathrm{Ru}]-\mathrm{C}=\mathrm{C}(\mathrm{Ph}) \mathrm{CHCN}(\mathbf{3 b})$ (Scheme 1). This reaction occurs only in acetone. The light-orange-yellow crystalline precipitate forms directly in the reaction mixture and can be obtained in analytically pure form by a simple filtration. No cyclopropenation reaction is observed in $\mathrm{CH}_{3} \mathrm{CN}$ or $\mathrm{MeOH}$. When the reaction is carried out at lower concentration, single crystals of 3b, suitable for X-ray diffraction analysis, are directly obtained. Reaction of $\mathbf{2 b}$ with $n$-Bu $\mathrm{Br}_{4} \mathrm{NF}(1 \mathrm{M}$ in THF) or DBU $(1,8-$ diazabicyclo[5.4.0] undecene) or $\mathrm{KOH}$ (dissolved in a minimum amount of $\mathrm{H}_{2} \mathrm{O}$ ) also yields $\mathbf{3 b}$. Complex $\mathbf{3 b}$ is stable in air and soluble in $\mathrm{CH}_{2} \mathrm{Cl}_{2}, \mathrm{CHCl}_{3}$, and THF but insoluble in diethyl ether, $n$-hexane, $\mathrm{MeOH}$, and $\mathrm{CH}_{3} \mathrm{CN}$.

The ${ }^{31} \mathrm{P}$ NMR spectrum of $\mathbf{3 b}$ displays resonances with the expected two doublets pattern $\left(\delta 49.7\right.$ and 51.6 with ${ }^{2} J_{\mathrm{P}-\mathrm{P}}=$ $34.6 \mathrm{~Hz}$ ) arising from the asymmetric three-membered ring. In the ${ }^{1} \mathrm{H}$ NMR spetrum of $\mathbf{3 b}$, the resonance of the methyne proton appears at $\delta 1.40$, and in the ${ }^{13} \mathrm{C}\left\{{ }^{1} \mathrm{H}\right\}$ NMR spectrum, a triplet at $\delta 126.2$ with ${ }^{2} J_{\mathrm{C}-\mathrm{P}}=23.5 \mathrm{~Hz}$ is assigned to the rutheniumbonded $\mathrm{C}_{\alpha}$ carbon.

(22) Ting, P. C.; Lin, Y. C.; Cheng, M. C.; Wang, Y. Organometallics 1994, 13, 2150 .

(23) (a) Allen, D. L.; Gibson, V. C.; Green, M. L.; Skinner, T. F.; Bashikin, J.; Grebenik, P. D. J. Chem. Soc., Chem. Commun. 1985, 895. (b) Consiglio, G.; Morandini, F. Chem. Rev. 1987, 87, 761. 


\section{Scheme 1}

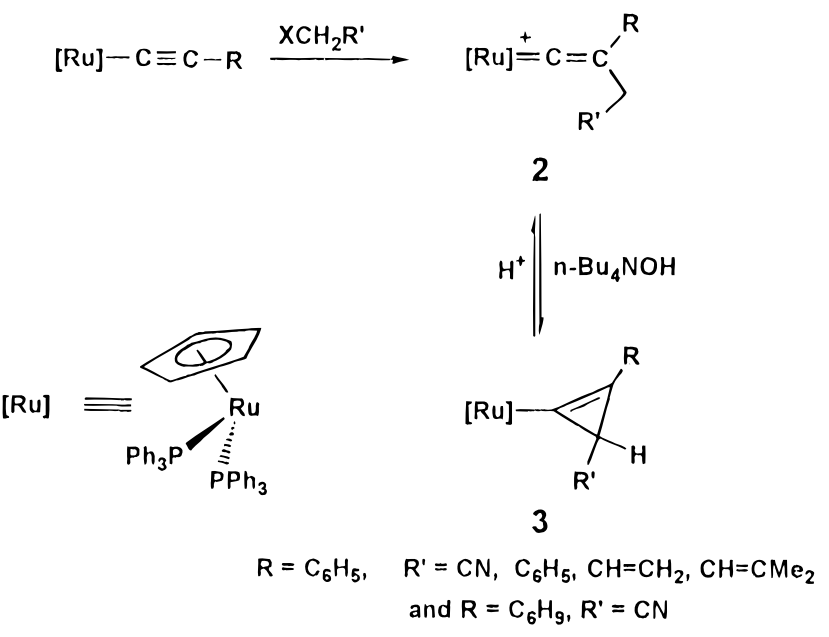

The deprotonation/cyclopropenation in acetone is a general reaction for a number of vinylidene complexes, namely, similar reactions are also known to occur for $\mathbf{2 c}, \mathbf{2 d}$, and $\mathbf{2 e}$, giving $[\mathrm{Ru}]-\mathrm{C}=\mathrm{C}(\mathrm{Ph}) \mathrm{CHR}\left(\mathbf{3 c}, \mathrm{R}=\mathrm{Ph} ; \mathbf{3 d}, \mathrm{R}=\mathrm{CH}=\mathrm{CH}_{2} ; \mathbf{3 e}, \mathrm{R}=\right.$ $\mathrm{CH}=\mathrm{CMe}_{2}$ ), respectively. Unlike $\mathbf{3 b}$, complexes $\mathbf{3 c}-\mathbf{e}$ can be obtained only by using $n-\mathrm{Bu}_{4} \mathrm{NOH}$ as proton abstractor and the reactions generally take longer. Complexes $\mathbf{3 b}-\mathbf{e}$ are stable in THF, but in $\mathrm{CHCl}_{3}$ compounds $\mathbf{3 c}, \mathbf{3 d}$, and $\mathbf{3 e}$ are less stable than 3b. Furthermore, $\mathbf{3 c}$ decomposes in $\mathrm{CDCl}_{3}$ producing $\mathrm{Cp}\left(\mathrm{PPh}_{3}\right)_{2} \mathrm{RuCl}$ and some unidentified organic products. Decomposition of $\mathbf{3 d}$ and $\mathbf{3 e}$ produces a complicated mixture. The stability of the cyclopropenyl complexes in $\mathrm{CHCl}_{3}$ follows the trend for the substituents of $\mathrm{CN}>\mathrm{Ph}>\mathrm{CH}=\mathrm{CH}_{2}>$ $\mathrm{CH}=\mathrm{CMe}_{2}$. The phenyl group on the $\mathrm{C}_{\gamma}$ is not essential since

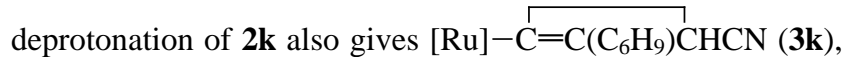
which exhibits better solubility in common organic solvents. Facile deprotonation indicates the acidic nature of the methylene protons of $\mathbf{2} \mathbf{b}-\mathbf{2 e}$ and $\mathbf{2 k}$, which may be ascribed to the combined effect of the cationic character, the electronwithdrawing substituent, and the benzylic/allylic property of the vinylidene complexes. $2 \mathbf{a}$ is inert toward $n-\mathrm{Bu}_{4} \mathrm{NOH}$ in acetone probably due to the lack of this acidic proton. It also appears that the hybridization of the $\mathrm{C}_{\delta}$ should either be $\mathrm{sp}$ or $\mathrm{sp}^{2}$ for the cyclopropenation to occur. However, the vinylidene complex with a propargyl substituent at $\mathrm{C}_{\beta}$ is too reactive to yield any isolable product. This is probably due to the presence of the acidic proton that complicates the outcome. When treated with nucleophiles, $\mathbf{2 b}$ fails to produce the intermolecular addition product. $^{24}$

Synthesis of metal cyclopropenyl derivatives in which the metal bonds to $\mathrm{C}\left(\mathrm{sp}^{3}\right)$ of the cyclopropene ring (in this case the three-membered ring can be viewed as an antiaromatic cyclopropenide ion) has been reported in the literature. ${ }^{25}$ However, to our knowledge, only one example of such a derivative in which the metal is bonded to the $\mathrm{C}\left(\mathrm{sp}^{2}\right)$ of the three-membered ring has been reported. ${ }^{26} \mathrm{~A}$ few structurally different transition metal cyclopropenylidene complexes, mostly prepared from dichlorocyclopropene ${ }^{27}$ and a number of $\pi$-cyclopropene com-

(24) (a) Davison, A.; Solar, J. P. J. Organomet. Chem. 1978, 155, C8. (b) Bell, R. A.; Chisholm, M. H. Inorg. Chem. 1977, 16, 687.

(25) (a) Löwe, C.; Shklover, V.; Bosch, H. W.; Berke, H. Chem. Ber. 1993, 126, 1769. (b) Gompper, R.; Bartmann, E. Angew. Chem., Int. Ed. Engl. 1978, 17, 456. (c) DeSimone, D. M.; Desrosiers, P. J.; Hughes, R. P. J. Am. Chem. Soc. 1982, 104, 4842. (d) Hughes, R. P.; Donaldson, W. A. J. Am. Chem. Soc. 1982, 104, 4846. (e) Weiss, R.; Priesner, C. Angew. Chem., Int. Ed. Engl. 1978, 17, 457.

(26) Gompper, R.; Bartmann, E. Angew. Chem., Int. Ed. Engl. 1985, $24,209$.
Scheme 2

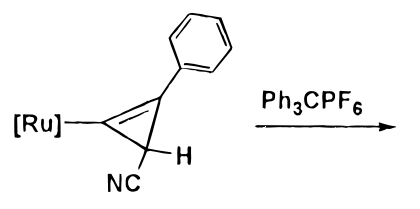<smiles>CC(C)[Mg]C#CC(c1ccccc1)C(C#N)c1ccccc1</smiles><smiles>CC(C)[14C]#C[C@H](c1ccccc1)[C@@H](Cl)C#N</smiles>

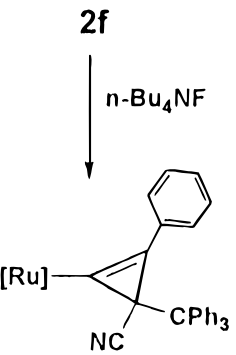

$2 g$

$3 f$

plexes, ${ }^{28}$ are also known. The acidity of the aliphatic protons on a coordinated dppe ligand in a cationic iron vinylidene complex ${ }^{29}$ has been employed for inducing the intramolecular cyclization between the dppe and vinylidene ligand.

Electrophilic Additions of Ruthenium Cyclopropenyl Complexes 3. Additions of $\mathrm{CF}_{3} \mathrm{COOH}$ to $\mathbf{3 b}-\mathbf{e}$ regenerate $\mathbf{2 b}-$ e, respectively, indicating the basic character of the methyne carbon of the three-membered ring. Furthermore, 3k was converted to $\mathbf{2 k}$ in $\mathrm{MeOH}$ indicating even stronger basicity. This protonation is different from the acid-induced demethoxylation of the iron cyclopropenyl complex. ${ }^{26}$ Attempts to remove hydrogen bonded to the three-membered ring using $\mathrm{Ph}_{3} \mathrm{C}^{+}$ yielded an unexpected product. Treatment of $\mathbf{3 b}$ with $\mathrm{Ph}_{3} \mathrm{C}^{+}$ affords $\left\{[\mathrm{Ru}]=\mathrm{C}=\mathrm{C}(\mathrm{Ph}) \mathrm{CH}\left(\mathrm{CPh}_{3}\right) \mathrm{CN}\right\}^{+}(\mathbf{2 f})$ with $64 \%$ yield. In this reaction, $\mathbf{2 b}$ is also isolated as a minor product (yield $<30 \%$, probably due to contamination of $\mathrm{HPF}_{6}$ in $\mathrm{Ph}_{3} \mathrm{CPF}_{6}$ ). Although $\mathrm{Ph}_{3} \mathrm{C}^{+}$is commonly used as a hydride abstraction reagent, ${ }^{30}$ as is evident from its reaction with several organic cyclopropenyl compounds, ${ }^{31}$ it however serves as an electrophile in the reaction with $\mathbf{3 b}$. There are a few examples in the literature in which electrophilic addition of $\mathrm{Ph}_{3} \mathrm{C}^{+}$resulted in the formation of the $\mathrm{C}-\mathrm{C}$ bond. ${ }^{32}$

Further deprotonation of the methyne proton of $\mathbf{2 f}$ by $n-\mathrm{Bu}_{4}$ -

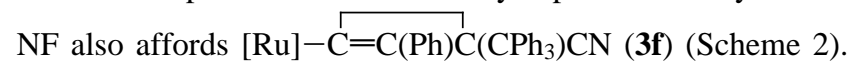
The yield is only $38 \%$ which may be attributed to the steric effect of the trityl cation. This same effect prevents protonation of $3 \mathbf{f}$ to yield $2 \mathbf{f}$. As expected, the ${ }^{31} \mathrm{P}$ NMR spectra of $\mathbf{2 f}$ and $\mathbf{3 f}$ both display two doublet resonances. Treatment of $\mathbf{3 b}$ with $\mathrm{HgCl}_{2}$ also produces a vinylidene product $\{[\mathrm{Ru}]=\mathrm{C}=\mathrm{C}(\mathrm{Ph})$ $\mathrm{CH}(\mathrm{HgCl}) \mathrm{CN}^{+}(\mathbf{2 g})$, with $81 \%$ yield. The formation of these

(27) (a) Kirchgassner, U.; Piana, H.; Schubert, U. J. Am. Chem. Soc. 1991, 113, 2228. (b) Miki, S.; Ohno, T.; Iwasaki, H.; Yoshida, Z. I. J. Phys. Org. Chem. 1988, 1, 333. (c) Yoshida, Z. I. Pure Appl. Chem. 1982, 54,1059 .

(28) (a) Schrock, R. R. Acc. Chem. Res. 1986, 19, 342. (b) Hughes, R. P.; Reisch, J. W.; Rheingold, A. L. Organometallics 1985, 4, 1754. (c) Hughes, R. P.; Kläui, W.; Reisch, J. W.; Müller, A.; Rheingold, A. L. Organometallics 1985, 4, 1761. (d) Mealli, C.; Midollini, S.; Moneti, S.; Sacconi, L.; Silvestre, J.; Albright, T. A. J. Am. Chem. Soc. 1982, 104, 59. (29) Adams, R. D.; Davison, A.; Selegue, J. P. J. Am. Chem. Soc. 1979, 101,7232 .

(30) (a) Casey, C. P.; Marder, S. R. Organometallics 1985, 4, 411. (b) Deeming, A. J.; Ullah, S. S.; Domingos, A. J. P.; Johnson, B. F. G.; Lewis, J. J. Chem. Soc., Dalton Trans. 1974, 2093.

(31) Zimmerman, H. E.; Aasen, S. M. J. Org. Chem. 1978, 43, 1493. (32) (a) Lewis, J.; Parkins, A. W. J. Chem. Soc. A 1967, 1150. (b) Schrock, R. R.; Johnson, B. F. G.; Lewis, J. J. Chem. Soc., Dalton Trans. 1974, 951. (c) Harris, P. J.; Knox, S. A. R.; McKinney, R. J.; Stone, F. G. A. J. Chem. Soc., Dalton Trans. 1978, 1009. 


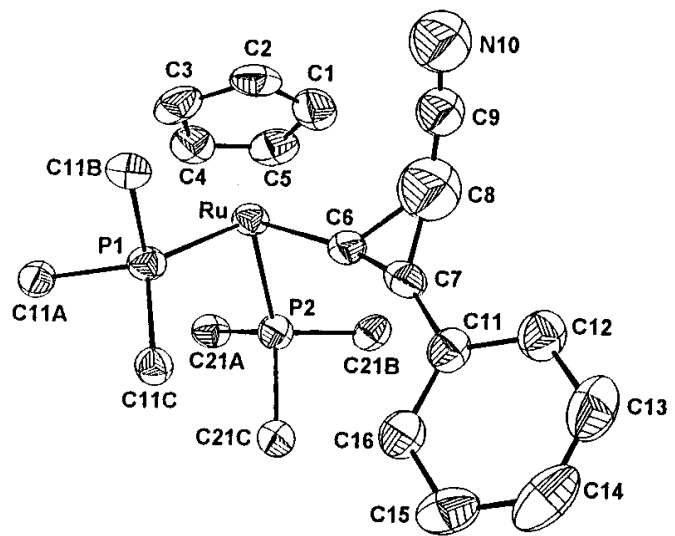

Figure 1. An ORTEP drawing (50\% thermal ellipsoid) of $\mathbf{3 b}$ with some of the phenyl groups on the phosphine ligands and hydrogen atoms eliminated for clarity. Selected bond distances $(\AA)$ and angles follow (deg): $\mathrm{Ru}-\mathrm{C}(6), 2.034(5) ; \mathrm{C}(6)-\mathrm{C}(7), 1.289(8) ; \mathrm{C}(6)-\mathrm{C}(8)$, 1.579(10); $\mathrm{C}(7)-\mathrm{C}(8), 1.452(10) ; \mathrm{C}(8)-\mathrm{C}(9), 1.215(16) ; \mathrm{C}(9)-\mathrm{N}(10)$, 1.102(18); $\mathrm{Ru}-\mathrm{C}(6)-\mathrm{C}(7), 169.7(4) ; \mathrm{Ru}-\mathrm{C}(6)-\mathrm{C}(8), 130.4(4) ; \mathrm{C}(7)-$ $\mathrm{C}(6)-\mathrm{C}(8), 59.8(4) ; \mathrm{C}(6)-\mathrm{C}(7)-\mathrm{C}(8), 70.1(5) ; \mathrm{C}(6)-\mathrm{C}(8)-\mathrm{C}(7), 50.1-$ (4); $\mathrm{C}(8)-\mathrm{C}(9)-\mathrm{N}(10), 170.1(13)$.

vinylidene complexes occurs by selective cleavage of the cyclopropenyl single bond near the metal center. This selectivity is similar to what has been reported for the unsymmetrical cyclopropenes where the methyl-substituted single bond is cleaved. $^{33}$ Attempts to carry out cyclopropenation of $\mathbf{2 g}$ by using $n-\mathrm{Bu}_{4} \mathrm{NOH}, n-\mathrm{Bu}_{4} \mathrm{NF}$, and $\mathrm{DBU}$ result in cleavage of the $\mathrm{C}-\mathrm{Hg}$ bond yielding $\mathbf{3 b}$.

Structures of Two Ru Cyclopropenyl Complexes. The molecular structures of $\mathbf{3 b}$ and $\mathbf{3 f}$ have been determined by $\mathrm{X}$-ray diffraction studies. The two optical isomers of $\mathbf{3} \mathbf{b}$ have been observed to crystallize together. An ORTEP drawing of one isomer of $\mathbf{3 b}$ is shown in Figure 1. The $\mathrm{Ru}-\mathrm{C}(6)$ bond length of 2.034(5) $\AA$ is typical for a $\mathrm{Ru}-\mathrm{C}$ single bond and the $\mathrm{C}(6)-\mathrm{C}(7)$ bond length of $1.289(8) \AA$ is a double bond, indicating the coordination of the $\mathrm{sp}^{2}$ carbon of the cyclopropenyl ligand. The bond angles $\mathrm{Ru}-\mathrm{C}(6)-\mathrm{C}(7)$ and $\mathrm{C}(6)-$ $\mathrm{C}(7)-\mathrm{C}(11)$ of $169.7(4)^{\circ}$ and $156.2(5)^{\circ}$, respectively, are both far greater than that of an idealized $\mathrm{C}\left(\mathrm{sp}^{2}\right)$ hybridization. The $\mathrm{C}(6)-\mathrm{C}(8)$ and $\mathrm{C}(7)-\mathrm{C}(8)$ bond lengths of $1.58(1)$ and 1.45(1) $\AA$, respectively, are significantly different, conforming with the favorable cleavage of the $\mathrm{C}(6)-\mathrm{C}(8)$ bond described above. The phenyl group on the three-membered ring is approximately coplanar with the cyclopropene and lies far away from the $\mathrm{Cp}$. An ORTEP drawing of $\mathbf{3 f}$ is shown in Figure 2. The $\mathrm{C}(6)-$ $\mathrm{C}(7)$ and $\mathrm{C}(7)-\mathrm{C}(9)$ bond lengths of $1.59(2)$ and 1.50(2) $\AA$, respectively, again differ significantly. The phenyl ring on $\mathrm{C}_{\beta}$ is no longer parallel to the three-membered ring, probably due to the steric hindrance between the $\mathrm{CPh}_{3}$ unit and the phenyl group on the cyclopropenyl moiety. This also indicates that formation of the three-membered ring does not require the presence of the phenyl group on $\mathrm{C}_{\beta}$.

Another type of Cyclization Induced by Base. Deprotonation of $[\mathrm{Ru}]=\mathrm{C}=\mathrm{C}(\mathrm{Ph}) \mathrm{CH}_{2} \mathrm{COOMe}^{+}, \mathbf{2} \mathbf{h}$, by $n-\mathrm{Bu}_{4} \mathrm{NOH}$ at room temperature induces a different type of cyclization yielding the neutral furan complex $[\mathrm{Ru}]-\mathrm{C}=\mathrm{C}(\mathrm{Ph}) \mathrm{CH}=\mathrm{C}(\mathrm{OMe}) \mathrm{O}$ (4h) (Scheme 3). Similar to cyclopropenation, this reaction also occurs only in acetone. $4 \mathrm{~h}$ is additionally obtained if $n-\mathrm{Bu}_{4} \mathrm{NF}$ or DBU is used. The most characteristic feature in the ${ }^{31} \mathrm{P}$ NMR spectrum of $\mathbf{4 h}$ is a singlet resonance at $\delta 51.3$ indicating lack of an asymmetric center. Also noticeable in the ${ }^{13} \mathrm{C} \mathrm{NMR}$

(33) Padwa, A.; Blocklock, T. J.; Getman, D.; Hatanaka, N.; Loza, R. J. Org. Chem. 1978, 43, 1481.

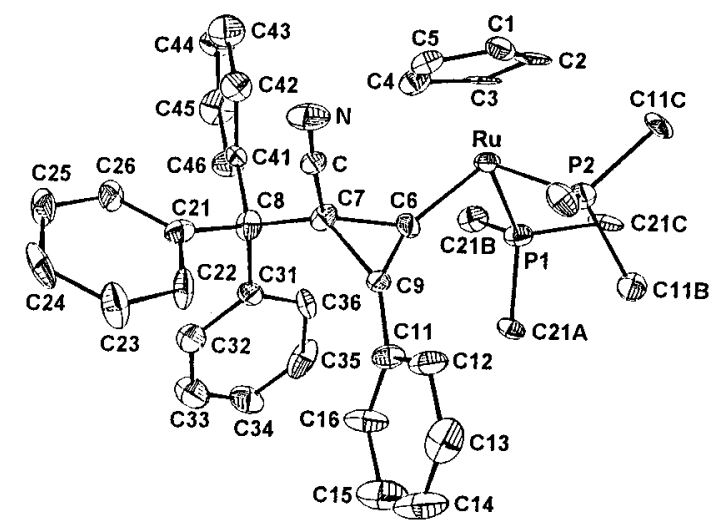

Figure 2. An ORTEP drawing (33\% thermal ellipsoid) of $\mathbf{3 f}$ with some of the phenyl groups on the phosphine ligands and hydrogen atoms eliminated for clarity. Selected bond distances $(\AA)$ and angles follow (deg): $\mathrm{Ru}-\mathrm{C}(6), 2.069(14) ; \mathrm{C}(6)-\mathrm{C}(7), 1.589(18) ; \mathrm{C}(6)-\mathrm{C}(9), 1.332-$ (20); $\mathrm{C}(7)-\mathrm{C}(9), 1.503(19) ; \mathrm{C}(7)-\mathrm{C}(8), 1.584(19) ; \mathrm{C}(7)-\mathrm{C}(10), 1.522-$ (19); $\mathrm{C}(10)-\mathrm{N}, 1.129(18) ; \mathrm{Ru}-\mathrm{C}(6)-\mathrm{C}(9), 157.1(11) ; \mathrm{Ru}-\mathrm{C}(6)-\mathrm{C}(7)$, 139.1(10); $\mathrm{C}(7)-\mathrm{C}(6)-\mathrm{C}(9), 61.2(9) ; \mathrm{C}(6)-\mathrm{C}(7)-\mathrm{C}(9), 51.0(8) ; \mathrm{C}(6)-$ $\mathrm{C}(9)-\mathrm{C}(7), 67.9(10) ; \mathrm{C}(7)-\mathrm{C}(10)-\mathrm{N}, 175.7(14)$

spectrum is the presence of a triplet resonance at $\delta 154.6\left(J_{\mathrm{C}-\mathrm{P}}\right.$ $=19.0 \mathrm{~Hz}$ ) assignable to $\mathrm{C}_{\alpha}$. By monitoring the reaction using

${ }^{31} \mathrm{P}$ NMR spectroscopy, $[\mathrm{Ru}]-\mathrm{C}=\mathrm{C}(\mathrm{Ph}) \mathrm{CHCOOMe}(\mathbf{3 h})$ was also observed at the initial stage of the reaction which gets converted to $\mathbf{4 h}$ in acetone within $30 \mathrm{~min}$ at room temperature. The reaction, if carried out at $5{ }^{\circ} \mathrm{C}$, yields $3 \mathbf{h}$ as a major product and $\mathbf{1 a}$ as a minor product, without formation of $\mathbf{4 h}$. Complex $\mathbf{3 h}$ in $\mathrm{MeOH}$ is susceptible to protonation whereas no reaction is observed between $\mathbf{4 h}$ and $\mathrm{MeOH}$. However, protonation of 4h by acetic acid regenerates $2 \mathrm{~h}$ quantitatively.

Owing to high strain energy of the cyclopropene ring, a more stable five-membered furan ring is expected to be the thermodynamic product. The fact that formation of $\mathbf{3 h}$ can be observed may imply that the deprotonation step yields a zwitterionic transition state with two resonance forms $\mathbf{A}$ (keto ester) and $\mathbf{B}$ (enol ester) (Scheme 3), which subsequently produce $\mathbf{3 h}$ and $4 \mathrm{~h}$, respectively. Lack of $4 \mathrm{~h}$ in the products at $5{ }^{\circ} \mathrm{C}$ can be interpreted in terms of the absence of enol form $\mathbf{B}$ at this temperature. The formation of $\mathbf{3 h}$ is favored by the proximity of $\mathrm{C}_{\alpha}$ and $\mathrm{C}_{\gamma}$ of the vinylidene ligand in $\mathbf{2 h}$ as well as lower mobility of the ester group at low temperature.

The thermal or photochemical ring opening of substituted cyclopropenes affords vinylcarbene intermediates in a reversible manner. Numerous examples of trapping of these species have been reported. ${ }^{34}$ Cyclizations of alkynol and epoxyalkyne catalyzed by Mo complex have also been recently reported. ${ }^{35}$ In these reactions, vinylidene and epoxyvinylidene have been proposed as intermediates. The effect of substituents on the selectivity of vinylcarbene formation depends upon whether thermal or photochemical activation is used, which is exam-

(34) (a) Davis, J. H.; Goddard, W. A., III; Bergman, R. G. J. Am. Chem. Soc. 1976, 98, 4015. (b) Streeper, R. D.; Gardner, P. D. Tetrahedron Lett. 1973, 767. (c) York, E. J.; Dittmar, W.; Stevenson, J. R.; Bergman, R. G. J. Am. Chem. Soc. 1972, 94, 2882; 1973, 95, 5680.

(35) McDonald, F. E.; Schultz, C. C. J. Am. Chem. Soc. 1994, 116, 9363.

(36) (a) Pincock, J. A.; Moutsokapas, A. Can. J. Chem. 1977, 55, 979. (b) Komendantov, M. I.; Domnin, I. N.; Bulueheva, E. V. Tetrahedron 1975, 31, 2495.

(37) (a) Trost, B. M.; Flygare, J. A. J. Org. Chem. 1994, 59, 1078. (b) Katritzky, A. R.; Li, J.; Gordeev, M. F. J. Org. Chem. 1993, 58, 3038. (c) Tani, K.; Sato, Y.; Okamoto, S.; Sato, F. Tetrahedron Lett. 1993, 34, 4975. (d) Arcadi, A.; Cacchi, S.; Larock, R. C.; Marinelli, F. Tetrahedron Lett. 1993, 34, 2813. (e) Marshall, J. A.; DuBay, W. J. J. Am. Chem. Soc. 1992, 114, 1450. (f) Fukuda, Y.; Shiragami, H.; Utimoto, K.; Nozaki, H. J. Org. Chem. 1991, 56, 5816. (g) Takai, K.; Tezuka, M.; Kataoka, Y.; Utimoto, K. J. Org. Chem. 1990, 55, 5310. 


\section{Scheme 3}
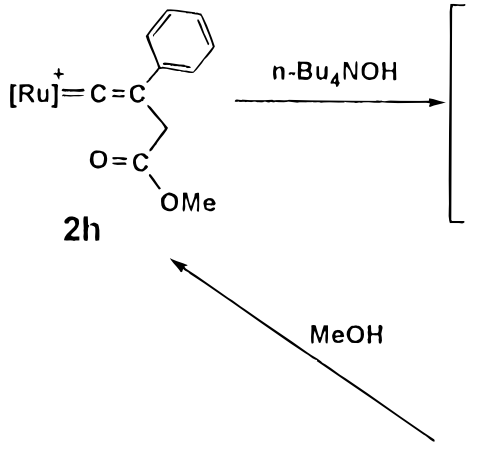

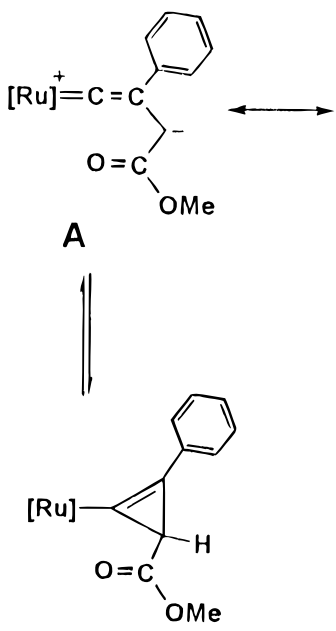

$3 \mathrm{~h}$<smiles>COC(=O)C=C(C#CC(C)C)c1ccccc1</smiles>

B

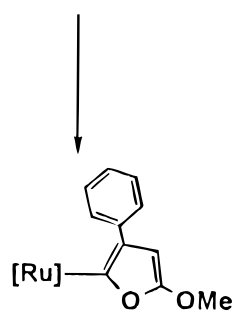

$4 h$ plified by the reactions of ester resulting in the production of furans. ${ }^{36}$ Several methods have recently been developed for furan synthesis. ${ }^{37}$ Other middle and late transition metal complexes react with terminal alkynols to give cyclic oxacarbenes. ${ }^{38}$

Structure of the Ru Furan Complex. The molecular structure of $\mathbf{4 h}$ has been determined by X-ray diffraction analysis. The crystal is found to contain two independent molecules, but with no essential structural difference between them. An ORTEP drawing of one molecule is shown in Figure 3. The $\mathrm{Ru}-\mathrm{C}(1 \mathrm{~A})$ bond length of 2.076(7) $\AA$ indicates a $\mathrm{Ru}-\mathrm{C}$ single bond and the $\mathrm{C}(1 \mathrm{~A})-\mathrm{C}(2 \mathrm{~A})$ and $\mathrm{C}(9 \mathrm{~A})-\mathrm{C}(10 \mathrm{~A})$ bond lengths of 1.370(9) and 1.33(1) $\AA$, respectively, are typical $\mathrm{C}=\mathrm{C}$ double bonds. As for the similar bonds in the three-membered ring of $\mathbf{3 b}$ and $\mathbf{3 f}$, the $\mathrm{C}(1 \mathrm{~A})-\mathrm{O}(1 \mathrm{~A})$ bond length of $1.442(8)$ $\AA$ near the $\mathrm{Ru}$ center in the five-membered ring is significantly longer than the $\mathrm{C}(10 \mathrm{~A})-\mathrm{O}(1 \mathrm{~A})$ bond length of $1.347(8) \AA$. This is consistent with the result of protonation reaction in which

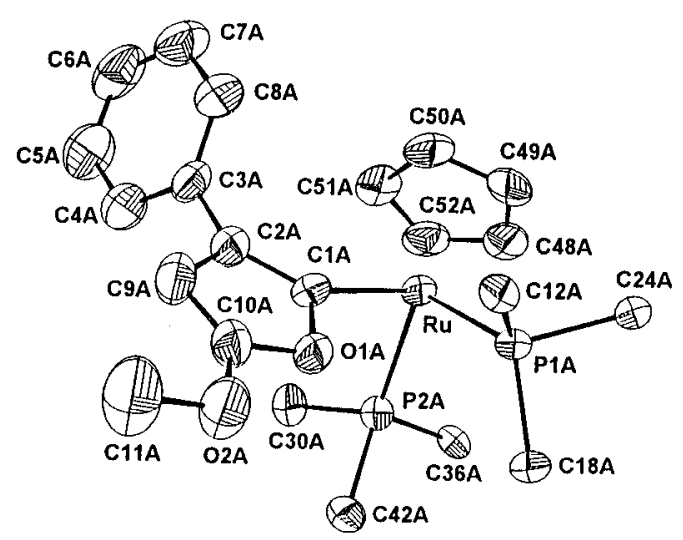

Figure 3. An ORTEP drawing (50\% thermal ellipsoid) of $\mathbf{4 h}$ with some of the phenyl groups on the phosphine ligands and hydrogen atoms eliminated for clarity. Selected bond distances $(\AA)$ and angles follow (deg): $\mathrm{Ru}-\mathrm{C}(1 \mathrm{~A}), 2.076(7)$; $\mathrm{C}(1 \mathrm{~A})-\mathrm{C}(2 \mathrm{~A}), 1.370(9)$; $\mathrm{C}(1 \mathrm{~A})-$ $\mathrm{O}(1 \mathrm{~A}), 1.442(8)$; $\mathrm{C}(2 \mathrm{~A})-\mathrm{C}(9 \mathrm{~A}), 1.454(10)$; $\mathrm{C}(9 \mathrm{~A})-\mathrm{C}(10 \mathrm{~A}), 1.330-$ (10); $\mathrm{C}(10 \mathrm{~A})-\mathrm{O}(1 \mathrm{~A}), 1.347(8) ; \mathrm{C}(10 \mathrm{~A})-\mathrm{O}(2 \mathrm{~A}), 1.358(9) ; \mathrm{O}(2 \mathrm{~A})-$ $\mathrm{C}(11 \mathrm{~A}), 1.395(11) ; \mathrm{Ru}-\mathrm{C}(1 \mathrm{~A})-\mathrm{C}(2 \mathrm{~A}), 140.0(5) ; \mathrm{Ru}-\mathrm{C}(1 \mathrm{~A})-\mathrm{O}(1 \mathrm{~A})$, 115.7(4); $\mathrm{O}(1 \mathrm{~A})-\mathrm{C}(1 \mathrm{~A})-\mathrm{C}(2 \mathrm{~A}), 104.3(5) ; \mathrm{C}(1 \mathrm{~A})-\mathrm{C}(2 \mathrm{~A})-\mathrm{C}(9 \mathrm{~A})$, 109.5(6); C(2A)-C(9A)-C(10A), 105.7(6); C(9A)-C(10A)-O(1A), 111.5(6); $\mathrm{C}(10 \mathrm{~A})-\mathrm{O}(1 \mathrm{~A})-\mathrm{C}(1 \mathrm{~A}), 109.0(5)$. the bond cleavage occurs at the $\mathrm{C}-\mathrm{O}$ bond near the $\mathrm{Ru}$ center. Interestingly, the phenyl ring is near the $\mathrm{Cp}$ unit in the solid state.

Unstable Vinyl Complex via Fluoride Attack at the $\boldsymbol{\alpha}$-Carbon. No deprotonation was observed in the reaction of $[\mathrm{Ru}]=\mathrm{C}=\mathrm{C}(\mathrm{Ph}) \mathrm{CH}_{2} \mathrm{OCH}_{3}{ }^{+}(\mathbf{2} \mathbf{j})$ with $n-\mathrm{Bu}_{4} \mathrm{NOH}$ or $\mathrm{DBU}$ in acetone. With a donor oxygen atom in $\mathbf{2} \mathbf{j}$ it is not unexpected that the above-mentioned methodology is not suitable for the preparation of the methoxy-substituted cyclopropenyl complex even though the iron cyclopropenyl complex with a methoxy substituent has been reported previously. ${ }^{26}$ Upon adding $n$ - $\mathrm{Bu}_{4}$ $\mathrm{NF}$ to $\mathbf{2} \mathbf{j}$, a different but more conventional reaction pattern is observed. Namely the reaction produces a yellow metal vinyl complex $[\mathrm{Ru}]-\mathrm{C}(\mathrm{F})=\mathrm{C}(\mathrm{Ph}) \mathrm{CH}_{2} \mathrm{OCH}_{3}$ (5). In this case about $80 \%$ conversion occurred in acetone at $10{ }^{\circ} \mathrm{C}$. Complex $\mathbf{5}$ is soluble in $\mathrm{CHCl}_{3}$ and THF. However, upon dissolution at room temperature, complex $\mathbf{5}$ immediately converts back to $\mathbf{2 j}$. Therefore the spectroscopic data are obtained at $-40{ }^{\circ} \mathrm{C}$. In the ${ }^{13} \mathrm{C}$ NMR spectrum of $\mathbf{5}$, a doublet resonance $\left({ }^{3} J_{\mathrm{C}-\mathrm{F}}=21.8\right.$ $\mathrm{Hz})$ at $\delta 70.8$ (inverted in the DEPT-135 experiment) is assigned to the methylene carbon. The coupling constant $J_{\mathrm{P}-\mathrm{F}}=47 \mathrm{~Hz}$ of the doublet resonance at $\delta 50.2$ in the ${ }^{31} \mathrm{P}$ NMR spectrum is consistent with that of the triplet resonance in the ${ }^{19} \mathrm{~F}$ NMR spectrum.

The importance of ionic fluorides as proton abstractors in base-assisted reactions, ${ }^{39}$ and also as a source of fluorine atoms in the synthesis of orgnofluorine derivatives, ${ }^{40}$ has been well documented. It can thus be expected that there should be factors other than the basicity and nucleophilicity associated with the ionic fluoride that govern the reactions of $\mathbf{2 b}$ and/or $\mathbf{2} \mathbf{j}$ with $n$-Bu ${ }_{4} \mathrm{NF}$. These factors associated with $n$-Bu ${ }_{4} \mathrm{NF}$ are not yet clear.

(38) (a) Quayle, P.; Rahman, S.; Ward, E. L. M.; Herbert, J. Tetrahedron Lett. 1994, 35, 3801. (b) Hinkle, R. J.; Stang, P. J.; Arif, A. M. Organometallics 1993, 12, 3510. (c) Stang, P. J.; Huang, Y. H. J. Organomet. Chem. 1992, 431, 247. (d) Le Bozec, H.; Ouzzine, K.; Dixneuf, P. H. Organometallics 1991, 10, 2768. (e) O'Connor, J. M.; Pu, L.; Rheingold, A. L. J. Am. Chem. Soc. 1990, 112, 6232. (f) Ditz, K. H.; Sturm, W.; Alt, H. G. Organometallics 1987, 6, 1424. (g) Parlier, A.; Rudler, H. J. Chem. Soc., Chem. Commun. 1986, 514. (h) Curtis, P. J.; Davies, S. G. J. Chem. Soc., Chem. Commun. 1984, 747.

(39) (a) Clark, J. H. Chem. Rev. 1980, 80, 429. (b) Jakobson, G. G.; Akmentova, N. E. Synthesis 1983, 169. (c) Clark, J. H. J. Chem. Soc., Chem. Commun. 1978, 789. (d) Landini, D.; Maia, A.; Rampoldi, A. J. Org. Chem. 1989, 54, 328.

(40) (a) Chi, D. Y.; Kilbourn, M. R.; Katzenellenbogen, J. A. J. Org. Chem. 1987, 52, 658. (b) Haas, A.; Lieb, M. Chimia 1985, 39, 134 . (c) Cox, D. P.; Terpinsky, J.; Lawrynowicz, W. J. Org. Chem. 1984, 49, 3216. 


\section{Scheme 4}

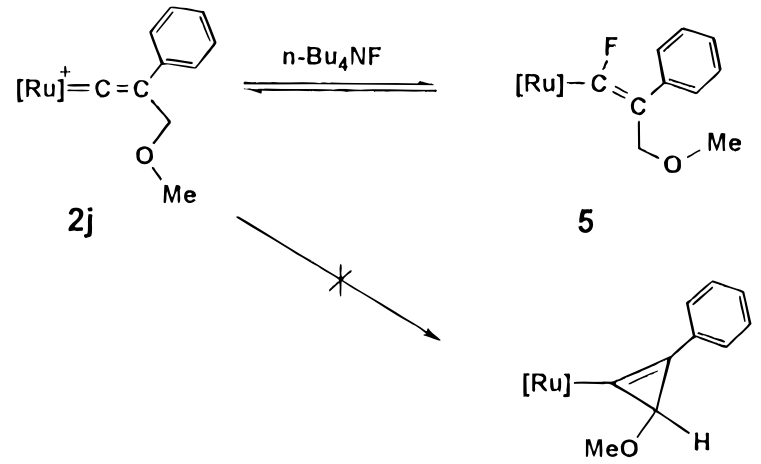

Scheme 5

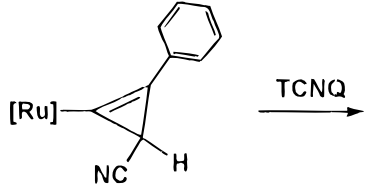

$3 b$

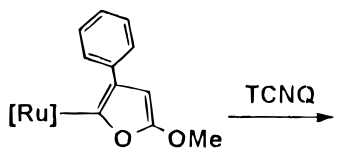

$4 \mathrm{~h}$<smiles>C=CC1C(c2ccccc2)=C1C(C)C</smiles>

$3 d$

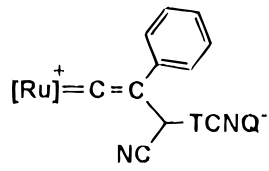

$6 b$<smiles>COC(=O)C(C(=O)[O-])c1ccccc1</smiles>

$6 h$<smiles>CC(C)C#CC(=C=CC[Te])c1ccccc1</smiles>

$7 d$
Electrophilic Addition of TCNQ to Cyclopropenyl Complexes. By comparing the protonation reactions of our neutral cyclopropenyl complexes, which lead to formation of cationic vinylidene complexes, with the same type of reaction of a similar complex reported in the literature, ${ }^{26}$ it can be noted that the complex consisting of a methoxy substituent, which leads to cyclopropenylium complex upon protonation, behaves very differently from those without such a group. It is thus clear that the $\mathrm{sp}^{3}$ carbon center of the cyclopropenyl complexes 3 without an alkoxy group is an electron-rich center. Thus it would be impossible to use the simple nucleophilic substitution reaction for direct addition of groups such as $-\mathrm{CN}$ or $-\mathrm{OMe}$ to the three-membered ring. However, by using TCNQ $\left[(\mathrm{NC})_{2} \mathrm{C}\left(\mathrm{C}_{6} \mathrm{H}_{4}\right) \mathrm{C}(\mathrm{CN})_{2}\right]$, it becomes viable to first add nucleophiles to the cyclopropenyl $\mathrm{C}_{\alpha}$ and then transfer to the $\mathrm{C}_{\beta}$ carbon leading to formation of various $\mathrm{MeO}$-substituted complexes. The following section describes the chemical reactivity of various complexes involving TCNQ.

Addition of TCNQ to $\mathbf{3 b}$ yielded the zwitterionic complex $[\mathrm{Ru}]=\mathrm{C}=\mathrm{C}(\mathrm{Ph}) \mathrm{CH}(\mathrm{CN})(\mathrm{TCNQ})(\mathbf{6 b})$ (Scheme 5). One terminus of TCNQ probably acts as an electrophile, adding to the methyne carbon and resulting in the formation of a $\mathrm{C}-\mathrm{C}$ bond. An alternative pathway would be a single electron transfer (SET) process $^{41}$ followed by a subsequent fast $\mathrm{C}-\mathrm{C}$ bond formation

(41) (a) Tanko, J. M.; Drumright, R. E.; Suleman, N. K.; Brammer, L. E. J. Am. Chem. Soc. 1994, 116, 1785. (b) Tolbert, L. M.; Sun, X. J.; Ashby, E. C. J. Am. Chem. Soc. 1995, 117, 2681.

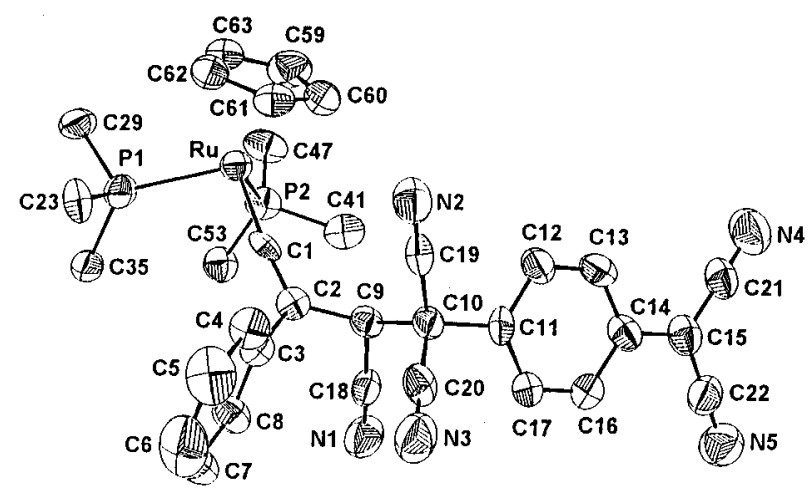

Figure 4. An ORTEP drawing (50\% thermal ellipsoid) of $\mathbf{6 b}$ with some of the phenyl groups on the phosphine ligands and hydrogen atoms eliminated for clarity. Selected bond distances $(\AA)$ and angles follows (deg): $\mathrm{Ru}-\mathrm{C}(1), 1.811(10) ; \mathrm{C}(1)-\mathrm{C}(2), 1.328(14) ; \mathrm{C}(2)-\mathrm{C}(9)$, 1.542(15); C(9)-C(10), 1.602(14); C(10-C(11), 1.546(15); C(11)$\mathrm{C}(12), 1.379(15) ; \mathrm{C}(12)-\mathrm{C}(13), 1.358(16) ; \mathrm{C}(13)-\mathrm{C}(14), 1.416(16)$; $\mathrm{C}(14)-\mathrm{C}(15), 1.426(16) ; \mathrm{C}(14)-\mathrm{C}(16), 1.393(16) ; \mathrm{C}(16)-\mathrm{C}(17)$, $1.365(16) ; \mathrm{C}(11)-\mathrm{C}(17), 1.380(15) ; \mathrm{C}(9)-\mathrm{C}(18), 1.486(15) ; \mathrm{C}(10)-$ $\mathrm{C}(19), 1.490(15) ; \mathrm{C}(10)-\mathrm{C}(20), 1.442(15) ; \mathrm{C}(15)-\mathrm{C}(21), 1.397(16)$; $\mathrm{C}(15)-\mathrm{C}(22), 1.390(17) ; \mathrm{C}(18)-\mathrm{N}(1), 1.116(14) ; \mathrm{C}(19)-\mathrm{N}(2), 1.120$ (14); $\mathrm{C}(20)-\mathrm{N}(3), 1.111(15) ; \mathrm{C}(21)-\mathrm{N}(4), 1.143(15) ; \mathrm{C}(22)-\mathrm{N}(5)$, 1.147(16); $\mathrm{Ru}-\mathrm{C}(1)-\mathrm{C}(2), 173.7(8) ; \mathrm{C}(1)-\mathrm{C}(2)-\mathrm{C}(9), 117.8(9)$; $\mathrm{C}(2)-\mathrm{C}(9)-\mathrm{C}(10), 114.6(8)$.

in the solvent cage. Complex $\mathbf{6 b}$, a light orange colored solid, displays a characteristic dark violet-red color in solution, and its spectroscopic data display the feature of a vinylidene complex. The pattern of two-doublet resonances at $\delta 40.6,38.8$ with $J_{\mathrm{P}-\mathrm{P}}=26.6 \mathrm{~Hz}$ in the ${ }^{31} \mathrm{P} \mathrm{NMR}$ spectrum arises from the asymmetric $\mathrm{C}_{\gamma}$ center. Localization of the negative charge at the free terminus of TCNQ causes the Ru center to display the cationic feature which is evidenced by chemical shift in these ${ }^{31} \mathrm{P}$ NMR resonances in the same region as that of other cationic complexes. The structure of $\mathbf{6} \mathbf{b}$ has also been determined by X-ray diffraction analysis. An ORTEP drawing is shown in Figure 4. The newly formed $\mathrm{C}(9)-\mathrm{C}(10)$ bond is rather weak as indicated by its extensively long bond length (1.60(1) $\AA$ ). Addition of TCNQ to $\mathbf{4 h}$ also opens up the five-membered ring and produces the zwitterionic complex $[\mathrm{Ru}]=\mathrm{C}=\mathrm{C}(\mathrm{Ph}) \mathrm{CH}$ (COOMe)(TCNQ) (6h) with $88 \%$ yield. Complex $\mathbf{6 h}$ has been characterized by spectroscopic methods. The ${ }^{31} \mathrm{P}$ NMR spectrum of $\mathbf{6 h}$ exhibits two doublets at $\delta 40.0$ and 38.7 which are very close to that of $\mathbf{6 b}$.

The reaction of TCNQ with $\mathbf{3 d}$ produces a different zwitterionic vinylidene complex $[\mathrm{Ru}]=\mathrm{C}=\mathrm{C}(\mathrm{Ph}) \mathrm{CH}=\mathrm{CHCH}_{2}(\mathrm{TCNQ})$, (7d) with TCNQ attached to the terminal carbon atom of the allylic unit (Scheme 5). This reaction has to be carried out at $-40{ }^{\circ} \mathrm{C}$ because of the higher reactivity of $3 \mathbf{d}$. The relatively more electron-rich vinyl group, instead of the $\mathrm{sp}^{3}$ carbon of the three-membered ring, of $\mathbf{3 d}$ serves as a better nucleophilic center. This causes a shift of the double bond to $\mathrm{C}_{\gamma}-\mathrm{C}_{\delta}$. Spectroscopic data clearly reveal the site of electrophilic addition. The doublet resonance at $\delta 2.64$, assignable to the $\mathrm{CH}_{2}$ group, in the ${ }^{1} \mathrm{H}$ NMR spectrum of $7 \mathbf{d}$ and the corresponding inverted resonance at $\delta 46.4$ in the ${ }^{13} \mathrm{C}$ NMR DEPT-135 clearly indicate an aliphatic $\mathrm{CH}_{2}$ unit in the molecule. A terminal vinyl group would give an inverted ${ }^{13} \mathrm{C}$ resonance for the $=\mathrm{CH}_{2}$ unit at a much lower field region. The coupling constant $J_{\mathrm{H}-\mathrm{H}}$ of $15.1 \mathrm{~Hz}$ between the olefinic protons indicates a trans configuration at the double bond. In the ${ }^{31} \mathrm{P} N M R$ spectrum, only a singlet resonance at $\delta 41.2$ was observed.

Cyclopropenyl Complexes with a Methoxy Substituent. Attempted deprotonation of $\mathbf{6 b}$ using $n-\mathrm{Bu}_{4} \mathrm{NOH}$ did not result in the formation of the expected cyclopropenyl complex 


\section{Scheme 6}

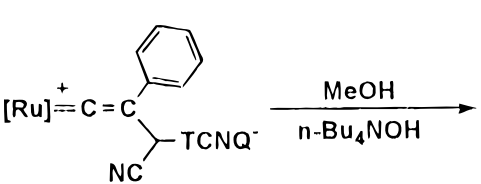

$6 b$

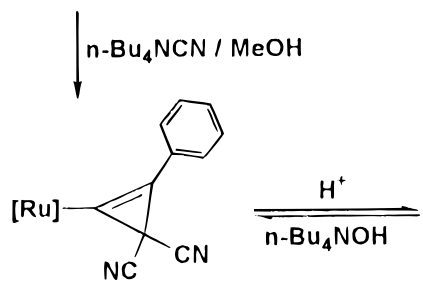

$3 m$

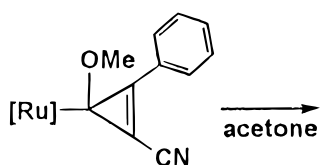

$8 b$<smiles>CC(C)C#CC(=CC(C)C)c1ccccc1</smiles>

$2 m$

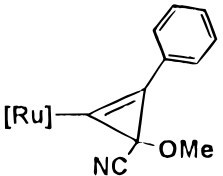

$9 b$
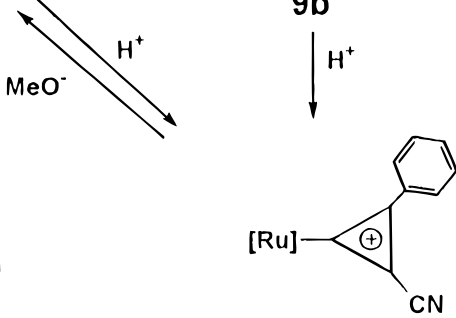

$10 \mathrm{~b}$

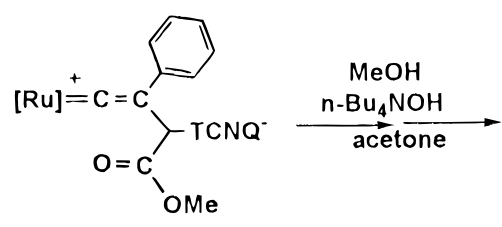

$6 h$

containing TCNQ. However, in this reaction, the solvent molecule of the added base, i.e. $\mathrm{MeOH}$, serves as a reactant in the presence of $n$ - $\mathrm{Bu}_{4} \mathrm{NOH}$ giving the light yellow complex $[\mathrm{Ru}]-\mathrm{C}=\mathrm{C}(\mathrm{Ph}) \mathrm{C}(\mathrm{OMe}) \mathrm{CN}(\mathbf{9 b})$ with $88 \%$ yield. In the absence of $n-\mathrm{Bu}_{4} \mathrm{NOH}$, no reaction occurred. The base system $n-\mathrm{Bu}_{4} \mathrm{NOH} / \mathrm{MeOH}$ however can be replaced by the $\mathrm{MeONa} /$ $\mathrm{MeOH}$ system. Replacing $\mathrm{MeOH}$ with $\mathrm{EtOH}$ yields the ethoxysubstituted product $[\mathrm{Ru}]-\mathrm{C}=\mathrm{C}(\mathrm{Ph}) \mathrm{C}(\mathrm{OEt}) \mathrm{CN}\left(\mathbf{9 \mathbf { b } ^ { \prime }}\right)$. The reagents without alcohol such as $n-\mathrm{Bu}_{4} \mathrm{NF} / \mathrm{THF}$ or DBU in THF result in formation of a complicated mixture. The steps that lead to the product are removal of proton by base accompanied by the cyclization, followed by displacing TCNQ with the OMe group. At the initial stage of this reaction in acetone, a mixture of two isomeric products $9 \mathrm{~b}$ and $[\mathrm{Ru}]-\mathrm{C}(\mathrm{OMe}) \mathrm{C}(\mathrm{Ph})=\mathrm{CCN}$ $(\mathbf{8 b})$, i.e. the methoxy group at $\mathrm{C}_{\alpha}$, is observed when the reaction is monitored by the ${ }^{31} \mathrm{P}$ NMR spectra (Scheme 6). Pure $\mathbf{8 b}$ can, however, be obtained by a different method which is described below. Complex $\mathbf{8 b}$ is stable in $\mathrm{CDCl}_{3}$ or in THF, but converts to $9 \mathbf{b}$ in acetone. In the ${ }^{31} \mathrm{P}$ NMR spectrum of $\mathbf{9 b}$ the characteristic two doublet resonances at $\delta 51.7,49.6$ with $J_{\mathrm{P}-\mathrm{P}}=36.0 \mathrm{~Hz}$ are observed whereas $\mathrm{C}_{\alpha}$ appears as a triplet resonance at $\delta 136.2$ with $J_{\mathrm{P}-\mathrm{C}}=19.8 \mathrm{~Hz}$ in the ${ }^{13} \mathrm{C} \mathrm{NMR}$ spectrum. For $9 \mathbf{b}^{\prime}$, in addition to the two-doublet ${ }^{31} \mathrm{P}$ resonances, the ${ }^{1} \mathrm{H}$ NMR spectrum displays resonances with two multiplet patterns which may be assigned to the $\mathrm{OCH}_{2}$ group and arise due to the chiral center of the three-membered ring.

The fact that base reagents without alcohol produce a complicated mixture probably indicates that the deprotonation is followed by various decomposition pathways. Furthermore, the fact that the reaction requires the presence of base leads us to believe that the deprotonation step may still be the first step in the formation of $\mathbf{9 b}$. Cleavage of the weak $\mathrm{C}_{\gamma}-\mathrm{C}$ (TCNQ) bond accompanying the attachment of the $\mathrm{MeO}$ group initially to $\mathrm{C}_{\alpha}$ followed by a shift to $\mathrm{C}_{\beta}$ satisfactorily accounts for the formation of $\mathbf{9 b}$. In the ${ }^{31} \mathrm{P}$ NMR spectrum of $\mathbf{8 b}$ the twodoublet (at $\delta 51.2$ and 50.7 with $J_{\mathrm{P}-\mathrm{P}}=29.6 \mathrm{~Hz}$ ) pattern arises<smiles>COC(=O)C1C(c2ccccc2)C1C(C)C</smiles>

$9 h$

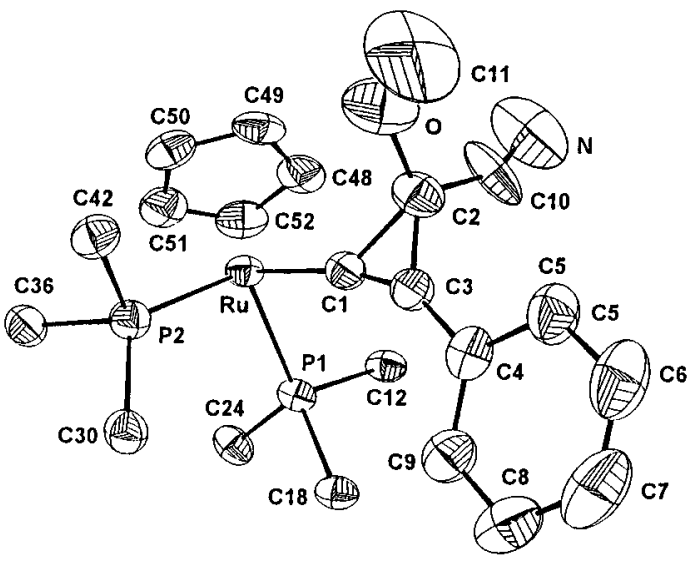

Figure 5. An ORTEP drawing (50\% thermal ellipsoid) of $\mathbf{9 b}$ with some of the phenyl groups on the phosphine ligands and hydrogen atoms eliminated for clarity. Selected bond distances $(\AA)$ and angles follow (deg): $\mathrm{Ru}-\mathrm{C}(1), 2.036(3) ; \mathrm{C}(1)-\mathrm{C}(2), 1.541(4) ; \mathrm{C}(1)-\mathrm{C}(3)$, $1.319(4) ; \mathrm{C}(2)-\mathrm{C}(3), 1.447(5) ; \mathrm{C}(2)-\mathrm{O}, 1.474(4) ; \mathrm{C}(2)-\mathrm{C}(10), 1.429$ (5); $\mathrm{C}(10)-\mathrm{N}, 1.098(5) ; \mathrm{O}-\mathrm{C}(11) ; 1.178(6) ; \mathrm{Ru}-\mathrm{C}(1)-\mathrm{C}(2), 132.1-$ (2); $\mathrm{Ru}-\mathrm{C}(1)-\mathrm{C}(3), 167.7(3) ; \mathrm{C}(2)-\mathrm{C}(1)-\mathrm{C}(3), 60.2(2) ; \mathrm{C}(1)-\mathrm{C}(2)-$ $\mathrm{C}(3), 52.3(2) ; \mathrm{C}(1)-\mathrm{C}(3)-\mathrm{C}(2), 67.5(2) ; \mathrm{C}(2)-\mathrm{O}-\mathrm{C}(11), 130.9(5)$; $\mathrm{C}(2)-\mathrm{C}(10)-\mathrm{N}, 156.0(5)$.

due to the chiral center at the ring. The ethyl analogue $\mathbf{8 \mathbf { b } ^ { \prime }}$ is kinetically more stable, i.e. at the initial stage of reaction only $\mathbf{8} \mathbf{b}^{\prime}$ was observed. In order to firmly establish the location of the methoxy group, the crystal structure of $\mathbf{9 b}$ has been determined. An ORTEP drawing of $\mathbf{9 b}$ is shown in Figure 5. The phenyl group on $\mathrm{C}_{\beta}$ is again approximately coplanar with the three-membered ring. Interestingly, a longer bond length of $\mathrm{C}(1)-\mathrm{C}(2)(1.541(4) \AA)$ as compared to that of $\mathrm{C}(2)-\mathrm{C}(3)$ $(1.447(5) \AA)$ is also observed.

Protonation of $\mathbf{8 b}$ or $\mathbf{9 b}$ removes the methoxy group and produces the cyclopropenylium complex, $[\mathrm{Ru}]-\mathrm{CC}(\mathrm{Ph}) \mathrm{CCN}^{+}$ (10b), with 78\% yield (Scheme 6). The symmetrical planar structure of the three-membered ring of $\mathbf{1 0 b}$ is revealed by the

${ }^{31} \mathrm{P}$ NMR spectrum, which shows only a singlet resonance at $\delta$ 
Scheme 7

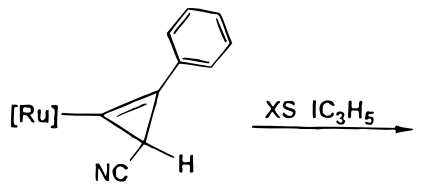

$3 b$

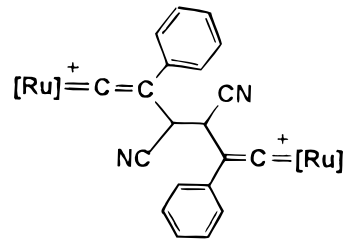

11
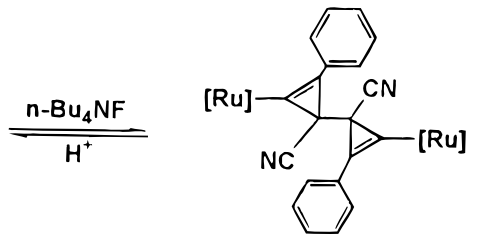

12
46.8. In the ${ }^{13} \mathrm{C}$ NMR spectrum the resonance attributed to the $\mathrm{C}_{\alpha}$ appears at $\delta 213.0$ with $J_{\mathrm{C}-\mathrm{P}}=17.2 \mathrm{~Hz}$. This reactivity is very different from opening of the three-membered ring of $\mathbf{3}$, yet similar to the reactivity of organic cyclopropene with a methoxy substituent. ${ }^{42}$ Reaction of MeONa with 10b in THF yields pure $\mathbf{8 b}$ which converts to $\mathbf{9 b}$ in acetone in about 40 min.

Similarly a suspension of complex $\mathbf{6 h}$ in acetone undergoes methanolysis to yield $[\mathrm{Ru}]-\mathrm{C}=\mathrm{C}(\mathrm{Ph}) \mathrm{C}\left(\mathrm{CO}_{2} \mathrm{Me}\right)(\mathrm{OMe})(\mathbf{9 h})$, another MeO-substituted cyclopropenyl complex with $60 \%$ yield (Scheme 6). The high solubility of $\mathbf{9 h}$ in acetone, however, hinders direct precipitation. The complex is hence purified by hexane extraction. The ${ }^{31} \mathrm{P}$ NMR (two doublets at $\delta 53.6$ and 48.0) and the ${ }^{1} \mathrm{H}$ NMR (two methyl resonances at $\delta 3.63$ and 3.29) spectra of $\mathbf{9 h}$ are consistent with its formulation. Unlike $\mathbf{3 h}$ which converts to $\mathbf{4 h}$, complex $\mathbf{9 h}$ stabilized by the methoxy group does not convert to a substituted furan. The threemembered ring of $9 \mathrm{~h}$ remains unchanged even at $45{ }^{\circ} \mathrm{C}$ in acetone. The effect of the $\mathrm{MeO}$ group in stabilizing the cyclopropenyl ring is consistent with what has been observed in many analogous organic compounds. ${ }^{42}$ With the TCNQ group present at a distant carbon atom, complex $\mathbf{7 d}$ is inert in $n-\mathrm{Bu}_{4} \mathrm{NOH} / \mathrm{MeOH}$. Protonation of $\mathbf{9 h}$ again removes the methoxy group giving the cationic cyclopropenylium complex $[\mathrm{Ru}]-\mathrm{CC}(\mathrm{Ph}) \mathrm{C}\left(\mathrm{CO}_{2} \mathrm{Me}\right)^{+}(\mathbf{1 0 h})$. The ${ }^{31} \mathrm{P}$ NMR spectrum of $\mathbf{1 0 h}$ displays only a singlet at $\delta 47.6$, characteristic of a cationic cyclopropenylium complex, where only one methyl resonance at $\delta 3.80$ is observed in the ${ }^{1} \mathrm{H}$ NMR spectrum.

However, the presence of a stronger nucleophile prohibits formation of the MeO-substituted complex 9. For example, the reaction of $n-\mathrm{Bu}_{4} \mathrm{NCN}$ in the presence of $\mathrm{MeOH}$ with $\mathbf{6} \mathbf{b}$ does not yield $9 \mathrm{~b}$ but brings about addition of the $\mathrm{CN}$ group with removal of TCNQ, giving $[\mathrm{Ru}]-\mathrm{C}=\mathrm{C}(\mathrm{Ph}) \mathrm{C}(\mathrm{CN})_{2},(\mathbf{3 m})$. Accompanied by deprotonation, the stronger nucleophile $\mathrm{CN}^{-}$ displaces TCNQ to form the product. Further protonation of 3m, lacking the $\mathrm{MeO}$ substituent, produces the vinylidene

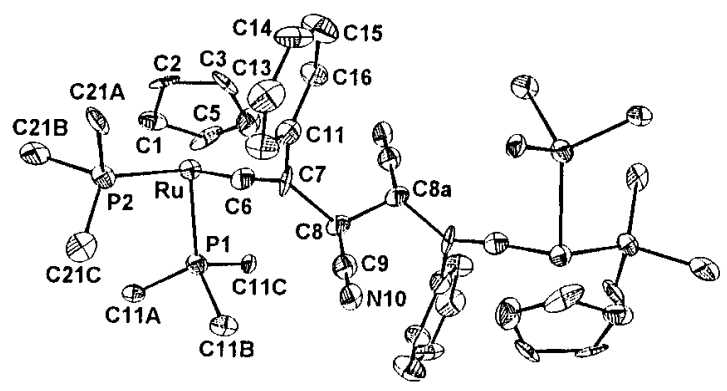

Figure 6. An ORTEP drawing (33\% thermal ellipsoid) of $\mathbf{1 1}$ with some of the phenyl groups on the phosphine ligands and hydrogen atoms eliminated for clarity. Selected bond distances $(\AA)$ and angles follow (deg): $\mathrm{Ru}-\mathrm{C}(6), 1.826(20) ; \mathrm{C}(6)-\mathrm{C}(7), 1.34(3) ; \mathrm{C}(7)-\mathrm{C}(8)$, 1.52(3); $\mathrm{C}(8)-\mathrm{C}(8 \mathrm{a}), 1.49(3) ; \mathrm{C}(8)-\mathrm{C}(9), 1.56(3) ; \mathrm{C}(9)-\mathrm{N}(10), 1.12-$ (3); $\mathrm{Ru}-\mathrm{C}(6)-\mathrm{C}(7), 174.4(16) ; \mathrm{C}(6)-\mathrm{C}(7)-\mathrm{C}(8), 120.6(17) ; \mathrm{C}(7)-$ $\mathrm{C}(8)-\mathrm{C}(8 \mathrm{a}), 114.7(16) ; \mathrm{C}(8)-\mathrm{C}(9)-\mathrm{N}(10), 178.1(20)$. complex $[\mathrm{Ru}]=\mathrm{C}=\mathrm{C}(\mathrm{Ph}) \mathrm{CH}(\mathrm{CN})_{2}{ }^{+}(\mathbf{2 m})$ instead of the cyclopropenylium complex (Scheme 6). This result further reveals the unique influence of the methoxy group present in the threemembered ring which effectively controls the protonation reaction of the cyclopropenyl complexes.

Oxidative Coupling Reactions of Metal Cyclopropenyl Complexes. On the basis of successful addition of the trityl group to $\mathbf{3 b}$, we attempted to induce a $\mathrm{C}-\mathrm{C}$ bond formation in 3b by using organic halides and found the formation of a new coupling product in the presence of allyl iodide. Treatment of 3b with a 20-fold excess of allyl iodide affords the dimeric dicationic vinylidene complex $\left\{[\mathrm{Ru}]=\mathrm{C}=\mathrm{C}(\mathrm{Ph}) \mathrm{CHCN}_{2}{ }_{2}^{2+}(\mathbf{1 1})\right.$ with $49 \%$ yield (Scheme 7). The yield of 11 depends on the amount of allyl iodide used. If only 1 equiv of allyl iodide is used, this reaction slowly produces $\mathbf{2 b}$ as a major product and only a trace amount of $\mathbf{1 1}$. Using other organic iodides such as methyl iodide, ethyl iodide, and iodobenzene produces no coupling product. The reactions of $\mathbf{3 c}$ or $\mathbf{3 d}$ with allyl iodide also do not produce the coupling product.

Complex $\mathbf{1 1}$ is insoluble in most of the organic solvents and only sparingly soluble in DMSO wherein it forms an orange solution. The mass spectrum of $\mathbf{1 1}$ is consistent with the formulation $\{[\mathrm{Ru}]=\mathrm{C}=\mathrm{C}(\mathrm{Ph}) \mathrm{CHCN}\}_{2} \mathrm{I}^{+}$. In the ${ }^{31} \mathrm{P} \mathrm{NMR}$ spectrum of 11, the chemical shift of the resonances at $\delta 41.3$ and 42.3 is close to that observed for 2 . The molecular structure of $\mathbf{1 1}$ has also been determined by X-ray diffraction analysis. Interestingly, the counterions in the solid state are two $\mathrm{I}_{3}{ }^{-}$ anions. A view of one molecule of $\mathbf{1 1}$ is shown in Figure 6. The center of the central $\mathrm{C}-\mathrm{C}$ bond lies on a center of symmetry, thus half of the molecule is symmetry-generated from the other. The $\mathrm{Ru}-\mathrm{C}(6)$ bond length of $1.83(2) \AA$ is consistent with the $\mathrm{Ru}=\mathrm{C}$ double bond formulation and the $\mathrm{Ru}-\mathrm{C}(6)-$ $\mathrm{C}(7)$ bond angle of $174(2)^{\circ}$ is similar to that in related vinylidene complexes.

The formation of $\mathbf{1 1}$ probably involves the cationic ruthenium vinylidene radical ${ }^{43}$ induced from the reaction of $\mathbf{3 b}$ with $\mathrm{C}_{3} \mathrm{H}_{5} \mathrm{I}$. The coupling of the allyl radical resulting in the formation of the bicyclopropyl molecule ${ }^{44}$ and radical annulations of allyl iodomalononitriles ${ }^{45}$ have been reported in the literature. Oxidative carbon-carbon coupling of the cationic iron vinylidene complex $[\mathrm{Cp}(\mathrm{dppe}) \mathrm{Fe}=\mathrm{C}=\mathrm{CHMe}]^{+}$leading to formation of $[\mathrm{Cp}(\mathrm{dppe}) \mathrm{Fe}=\mathrm{C}=\mathrm{CMe}]_{2}{ }^{2+}$ has been reported, ${ }^{46}$ whereas

(42) (a) Breslow, R.; Chang, H. W. J. Am. Chem. Soc. 1961, 83, 2367. (b) Krebs, A. W. Angew. Chem., Int. Ed. Engl. 1965, 4, 10. (c) Closs, G. L.; Boll, W. A.; Heyn, H.; Dev, V. J. Am. Chem. Soc. 1968, 90, 173.

(43) (a) Rabier, A.; Lugan, N.; Mathieu, R.; Geoffroy, G. L. Organometallics 1994, 13, 4676. (b) Antinolo, A.; Otero, A.; Fajardo, M.; GarciaYebra, C.; Gil-Sanz, R.; Lopez-Mardomingo, C.; Martin, A.; Gomez-Sal, P. Organometallics 1994, 13, 4679.

(44) Holtzhauer, K.; Cometta-Morini, C.; Oth, J. F. M. J. Phys. Org. Chem. 1990, 3, 219.

(45) Curran, D. P.; Seong, C. M. Tetrahedron 1992, 48, 2175.

(46) Lyer, R. S.; Selegue, J. P. J. Am. Chem. Soc. 1987, 109, 910.

(47) Le Narvor, N.; Toupet, L.; Lapinte, C. J. Am. Chem. Soc. 1995, 117,7129

(48) Connelly, N. G.; Gamasa, M. P.; Gimeno, J.; Lapinte, C.; Lastra, E.; Maher, J. P.; Le Narvor, N.; Rieger, A. L.; Rieger, P. H. J. Chem. Soc., Dalton Trans. 1993, 2575. 
another very similar coupling 47 has been attributed to the presence of 17-electron species, confirmed by ESR. ${ }^{48}$ Unsubstituted vinylidene complex $\mathrm{Cp}\left(\mathrm{PPh}_{3}\right)_{2} \mathrm{Ru}=\mathrm{C}=\mathrm{CH}_{2}$ also undergoes oxidative coupling by MeI and produces a similar dimer. ${ }^{49}$ There are also few examples of metal acetylide couplings. ${ }^{50}$ The possible role of azavinylidene ${ }^{51}$ in the conversion of nitriles to diimido-bridged dimer in tantalum and niobium complexes ${ }^{52}$ has been recently addressed. These examples are, nevertheless, different from what is observed in $\mathbf{3 b}$, namely in our system the oxidative coupling at $\mathrm{C}_{\gamma}$ results in formation of a $\mathrm{C}_{6}$ bridge between the $\mathrm{Ru}$ metal centers. Complex 11 undergoes two deprotonation/cyclopropenation in the presence of excess $n$-Bu $\mathrm{Bu}_{4}$ $\mathrm{NOH}$ to give the neutral 2,2'-bicyclopropenyl complex $\{[\mathrm{Ru}]-$ $\mathrm{C}=\mathrm{C}(\mathrm{Ph}) \mathrm{CCN}_{2}$ (12). Complex 12 displays the typical light yellow orange color of the cyclopropenyl complexes. Product analyses included elementary analysis, mass spectroscopy, and ${ }^{1} \mathrm{H}$ NMR spectroscopy which shows characteristic $\mathrm{Cp}$ absorption at $\delta$ 4.87. Similar to 11, complex $\mathbf{1 2}$ also displays the characteristic $A B$ pattern in its ${ }^{31} \mathrm{P}$ NMR spectrum. The unsubstituted 2,2'-bicyclopropene has been prepared ${ }^{53}$ and its structure has been determined by X-ray diffraction analysis at $103 \mathrm{~K}^{54}$

Conclusion. The facile preparation of neutral $\mathrm{Ru}$ cyclopropenyl complexes has been achieved by deprotonation of a $\mathrm{CH}$ or $\mathrm{CH}_{2}$ unit at $\mathrm{C}_{\gamma}$ of the cationic vinylidene complexes in acetone. Successful accomplishment of the preparation of complexes with various substituents such as $\mathrm{CN}, \mathrm{Ph}$, and vinyl groups at $\mathrm{CH}$ or $\mathrm{CH}_{2}$ renders this preparation a potentially versatile synthetic method. The deprotonation of vinylidene complexes consisting of an ester group yields the five-membered furan moiety as thermodynamic products. Protonation of both of the cyclization products, yielding back the vinylidene complexes, shows the nucleophilic nature of the antecedent $\mathrm{C} \gamma$ carbon of the vinylidene ligand. Thus other electrophiles could also be added to this same $\mathrm{C} \gamma$ site by reaction with cyclopropenyl or furan complex. However, when TCNQ was employed for this purpose, the addition could be modified leading eventually to the formation of cyclopropenyl complex with a methoxy substituent, which displays higher stability of the threemembered ring and shows particular reactivity. Thus in the present system, use of TCNQ appears to serve as an entry to the cyclopropenylium complex. A cyclopropenyl complex with a methoxy group behaves differently from that without such a unit.

\section{Experimental Section}

General Procedures. All manipulations were performed under nitrogen using vacuum-line, dry box, and standard Schlenk techniques. $\mathrm{CH}_{3} \mathrm{CN}$ and $\mathrm{CH}_{2} \mathrm{Cl}_{2}$ were distilled from $\mathrm{CaH}_{2}$ and diethyl ether and THF from Na/ketyl. All other solvents and reagents were of reagent grade and were used without further purification. NMR spectra were recorded on Bruker AC-200 and AM-300WB FT-NMR spectrometers at room temperature (unless states otherwise) and are reported in units

(49) Bruce, M. I.; Koutsantonis, G. A. Aust. J. Chem. 1991, 44, 207.

(50) (a) Shih, K.-Y.; Schrock, R. R.; Kempe, R. J. Am. Chem. Soc. 1994, 116, 8804. (b) Evans, W. T.; Keyer, R. A.; Ziller, J. W. Organometallics 1993, 12, 2618. (c) Shutowski, D. G.; Stucky, G. D. J. Am. Chem. Soc. 1976, 98, 1376.

(51) Feng, S. G.; White, P. S.; Templeton, J. L. J. Am. Chem. Soc. 1994, 116,8613 .

(52) (a) Finn, P. A.; King, M. S.; Kilty, P. A.; McCarley, R. E. J. Am. Chem. Soc. 1975, 97, 220. (b) Cotton, F. A.; Hall, T. W. Inorg. Chem. 1978, 17, 3525. (c) Roskamp, E. J.; Pedersen, S. F. J. Am. Chem. Soc. 1987, 109,3152 .

(53) Billups, W. E.; Haley, M. M. Angew. Chem., Int. Ed. Engl. 1989, $28,1711$.

(54) Bordalla, D.; Mootz, D.; Boese, R.; Osswald, W. J. Appl. Crystallogr. 1985, 18, 316 . of $\delta$ with residual protons in the solvent as an internal standard $\left(\mathrm{CDCl}_{3}\right.$, $\delta$ 7.24; $\left.\mathrm{CD}_{3} \mathrm{CN}, \delta 1.93 ; \mathrm{C}_{2} \mathrm{D}_{6} \mathrm{CO}, \delta 2.04\right)$. FAB mass spectra were recorded on a JEOL SX-102A spectrometer. Complexes 1a, $[\mathrm{Ru}]-$ $\mathrm{C} \equiv \mathrm{C}-\mathrm{C}_{6} \mathrm{H}_{9},{ }^{55} \mathbf{1 k}$, and $[\mathrm{Ru}]=\mathrm{C}=\mathrm{C}(\mathrm{Ph}) \mathrm{CH}_{2} \mathrm{R}^{+}(\mathbf{2} \mathbf{c}, \mathrm{R}=\mathrm{Ph} ; \mathbf{2 d}, \mathrm{R}=$ $\left.\mathrm{CH}=\mathrm{CH}_{2}\right)^{56}$ were prepared following the methods reported in the literature. Elemental analyses and X-ray diffraction studies were carried out at the Regional Center of Analytical Instrument located at the National Taiwan University.

Synthesis of $\left[[\mathbf{R u}]=\mathbf{C}=\mathbf{C}(\mathbf{P h}) \mathbf{C H}_{2} \mathbf{C N}\right]\left[\mathbf{P F}_{6}\right]$ (2b). A Schlenk flask was charged with complex $1 \mathbf{a}(0.475 \mathrm{~g}, 0.60 \mathrm{mmol})$ and $\mathrm{NH}_{4} \mathrm{PF}_{6}(0.123$ g, $0.75 \mathrm{mmol})$ and $\mathrm{CH}_{2} \mathrm{Cl}_{2}(20 \mathrm{~mL})$ were added after the atmosphere was replaced with nitrogen. The resulting solution was stirred at room temperature and $\mathrm{ICH}_{2} \mathrm{CN}(0.1 \mathrm{~mL}, 1.5 \mathrm{mmol})$ was added. The clear solution was stirred for $18 \mathrm{~h}$, then the solvent was reduced to about 5 $\mathrm{mL}$. This mixture was slowly added to $60 \mathrm{~mL}$ of vigorously stirred diethyl ether. The pale red precipitate thus formed was filtered off and washed with diethyl ether and hexane. The product was recrystallized from $\mathrm{CH}_{2} \mathrm{Cl}_{2} /$ hexane (1:5) and identified as $\mathbf{2 b}(0.42 \mathrm{~g}, 0.43 \mathrm{mmol}$, 72\%). Spectroscopic data of $\mathbf{2 b}$ : ${ }^{1} \mathrm{H}$ NMR $\mathrm{CD}_{3} \mathrm{COCD}_{3}: 8.16-7.03$ ( $\mathrm{Ph}) ; 5.61$ (s, 5H, Cp); 3.56 (s, 2H, $\left.\mathrm{CH}_{2}\right) .{ }^{13} \mathrm{C} \mathrm{NMR} \mathrm{CD}_{3} \mathrm{COCD}_{3}: 345.6$ $\left(\mathrm{t}, J_{\mathrm{P}-\mathrm{C}}=17.9 \mathrm{~Hz}, \mathrm{C}_{\alpha}\right) ; 134.8-128.4(\mathrm{Ph}) ; 123.0\left(\mathrm{C}_{\beta}\right) ; 118.5(\mathrm{CN})$; 95.6 (Cp); $14.5\left(\mathrm{CH}_{2}\right)$. ${ }^{31} \mathrm{P}$ NMR $\mathrm{CD}_{3} \mathrm{COCD}_{3}$ : 42.4 (s). MS FAB $m / z: 834\left(\mathrm{M}^{+}, \mathrm{Ru}=104\right), 572\left(\mathrm{M}^{+}-\mathrm{PPh}_{3}\right), 431\left(\mathrm{M}^{+}-\mathrm{PPh}_{3}, \mathrm{C}_{2^{-}}\right.$ $\mathrm{PhCH}_{2} \mathrm{CN}$ ). Anal. Calcd for $\mathrm{C}_{51} \mathrm{H}_{42} \mathrm{NP}_{3} \mathrm{~F}_{6} \mathrm{Ru}: \mathrm{C}, 62.70 ; \mathrm{H}, 4.33 ; \mathrm{N}$, 1.43. Found: $\mathrm{C}, 62.90 ; \mathrm{H}, 4.15 ; \mathrm{N}, 1.96$.

Complex $\left[[\mathrm{Ru}]=\mathrm{C}=\mathrm{C}(\mathrm{Ph}) \mathrm{CH}_{2} \mathrm{CH}=\mathrm{CMe}_{2}\right]\left[\mathrm{PF}_{6}\right](\mathbf{2 e})(0.84 \mathrm{~g}, 0.81$ mmol, $77 \%$ yield from $0.85 \mathrm{~g}$ of 1a) was similarly prepared from $\mathrm{BrCH}_{2} \mathrm{CH}=\mathrm{CMe}_{2}$. Spectroscopic data of $2 \mathrm{e}:{ }^{1} \mathrm{H} N M R \mathrm{CDCl}_{3}: 7.38-$ $6.85(\mathrm{~m}, 35 \mathrm{H}, \mathrm{Ph}) ; 5.04(\mathrm{~s}, 5 \mathrm{H}, \mathrm{Cp}) ; 4.92(\mathrm{~m}, 1 \mathrm{H},=\mathrm{CH}) ; 2.90(\mathrm{~d}$, $\left.J_{\mathrm{H}-\mathrm{H}}=6.5 \mathrm{~Hz}, 2 \mathrm{H}, \mathrm{CH}_{2}\right) ; 1.58,1.11\left(\mathrm{~s}, 6 \mathrm{H}, 2 \mathrm{CH}_{3}\right) .{ }^{13} \mathrm{C} \mathrm{NMR}$ $\mathrm{CDCl}_{3}: 348.9\left(\mathrm{t}, J_{\mathrm{P}-\mathrm{C}}=15.8 \mathrm{~Hz}, \mathrm{C}_{\alpha}\right) ; 134.7-124.7(\mathrm{Ph}) ; 119.8\left(\mathrm{C}_{\beta}\right)$; $94.1(\mathrm{Cp}) ; 25.8,25.6\left(2 \mathrm{CH}_{3}\right) ; 17.6\left(\mathrm{CH}_{2}\right) .{ }^{31} \mathrm{P} \mathrm{NMR} \mathrm{CDCl} 3: 42.7(\mathrm{~s})$. MS FAB $m / z: 863\left(\mathrm{M}^{+}\right), 601\left(\mathrm{M}^{+}-\mathrm{PPh}_{3}\right), 431\left(\mathrm{M}^{+}-\mathrm{PPh}_{3}, \mathrm{C}_{2^{-}}\right.$ $\mathrm{PhCH}_{2} \mathrm{CHCMe}_{2}$ ). Anal. Calcd for $\mathrm{C}_{54} \mathrm{H}_{49} \mathrm{P}_{3} \mathrm{~F}_{6} \mathrm{Ru}$ : C, 64.47; H, 4.91. Found: C, 64.80; H, 4.65.

Complex $\left[[\mathrm{Ru}]=\mathrm{C}=\mathrm{C}(\mathrm{Ph}) \mathrm{CH}_{2} \mathrm{COOMe}_{[}\left[\mathrm{PF}_{6}\right]\right.$ (2h) was prepared using the following method. A mixture of complex $1 \mathrm{a}(1.15 \mathrm{~g}, 1.45$ $\mathrm{mmol})$ and $\mathrm{BrCH}_{2} \mathrm{COOMe}(0.5 \mathrm{~mL}, 5.1 \mathrm{mmol})$ in $40 \mathrm{~mL}$ of $\mathrm{CH}_{2} \mathrm{Cl}_{2} /$ $\mathrm{CHCl}_{3}$ (3:1) was heated to refulx for $8 \mathrm{~h}$, then $\mathrm{NH}_{4} \mathrm{PF}_{6}(0.25 \mathrm{~g}, 1.53$ $\mathrm{mmol}$ ) was added and the mixture was stirred at room temperature for $4 \mathrm{~h}$. The workup procedure was the same as that for $\mathbf{2 b}$. Purification by recrystallization from $\mathrm{CH}_{2} \mathrm{Cl}_{2}$ /hexane (1:5) gave $2 \mathbf{h}(0.91 \mathrm{~g}, 0.90$ mmol, $62 \%$ yield). Spectroscopic data of $2 \mathbf{h}$ : ${ }^{1} \mathrm{H} \mathrm{NMR} \mathrm{CD}_{3} \mathrm{COCD}_{3}$ : 7.50-7.06 (m, 35H, Ph); 5.52 (s, 5H, Cp); 3.65 (s, 3H, $\left.\mathrm{CH}_{3}\right) ; 3.10(\mathrm{~s}$, $\left.2 \mathrm{H}, \mathrm{CH}_{2}\right) .{ }^{13} \mathrm{C} \mathrm{NMR} \mathrm{CDCl}_{3}: 347.8\left(\mathrm{~J}_{\mathrm{P}-\mathrm{C}}=14.6 \mathrm{~Hz}, \mathrm{C}_{\alpha}\right) ; 171.7(\mathrm{~s}$, $\left.\mathrm{CO}_{2}\right) ; 134.4-128.3(\mathrm{Ph}) ; 125.1\left(\mathrm{C}_{\beta}\right) ; 90.7(\mathrm{Cp}) ; 52.2\left(\mathrm{CH}_{3}\right) ; 32.1\left(\mathrm{CH}_{2}\right)$. ${ }^{31} \mathrm{P} \mathrm{NMR} \mathrm{CDCl}{ }_{3}: 42.0$ (s). MS FAB $m / z: 867\left(\mathrm{M}^{+}\right), 721\left(\mathrm{M}^{+}-\mathrm{C}_{2^{-}}\right.$ $\left.\mathrm{PhCH}_{2} \mathrm{COOMe}+\mathrm{CO}\right), 693\left(\mathrm{M}^{+}-\mathrm{C}_{2} \mathrm{PhCH}_{2} \mathrm{COOMe}\right), 431\left(\mathrm{M}^{+}-\right.$ $\mathrm{PPh}_{3}, \mathrm{C}_{2} \mathrm{PhCH}_{2} \mathrm{COOMe}$ ). Anal. Calcd for $\mathrm{C}_{52} \mathrm{H}_{45} \mathrm{O}_{2} \mathrm{P}_{3} \mathrm{~F}_{6} \mathrm{Ru}$ : C, 61.84; H, 4.49. Found: C, 62.23; $\mathrm{H}, 4.71$.

Complex $\left[[\mathrm{Ru}]=\mathrm{C}=\mathrm{C}(\mathrm{Ph}) \mathrm{CH}_{2} \mathrm{COOEt}\right]\left[\mathrm{PF}_{6}\right]$ (2i) was prepared in $68 \%$ isolated yield using the same procedure as that for $\mathbf{2 h}$. Spectroscopic data of $2 \mathbf{i}:{ }^{1} \mathrm{H} \mathrm{NMR} \mathrm{CDCl}_{3}: 7.40-6.88(\mathrm{~m}, 35 \mathrm{H}, \mathrm{Ph}) ; 5.22(\mathrm{~s}$, $5 \mathrm{H}, \mathrm{Cp}) ; 4.08\left(\mathrm{q}, J_{\mathrm{H}-\mathrm{H}}=7.13 \mathrm{~Hz}, 2 \mathrm{H}, \mathrm{OCH}_{2}\right) ; 3.00\left(\mathrm{~s}, 2 \mathrm{H}, \mathrm{CH}_{2}\right) ; 1.15$ $\left(\mathrm{t}, J_{\mathrm{H}-\mathrm{H}}=7.13 \mathrm{~Hz}, 3 \mathrm{H}, \mathrm{CH}_{3}\right) .{ }^{13} \mathrm{C} \mathrm{NMR} \mathrm{CDCl}_{3}: 347.8\left(J_{\mathrm{P}-\mathrm{C}}=15.1\right.$ $\left.\mathrm{Hz}, \mathrm{C}_{\alpha}\right) ; 171.2\left(\mathrm{~s}, \mathrm{CO}_{2}\right) ; 134.3-128.3(\mathrm{Ph}) ; 125.1\left(\mathrm{C}_{\beta}\right) ; 94.8(\mathrm{Cp}) ; 61.2$ $\left(\mathrm{CH}_{2} \mathrm{CO}_{2}\right) ; 32.3\left(\mathrm{OCH}_{2}\right) ; 14.1\left(\mathrm{CH}_{3}\right) .{ }^{31} \mathrm{P} \mathrm{NMR} \mathrm{CDCl} 3: 42.1$ (s). MS FAB $m / z: 882\left(\mathrm{M}^{+}\right), 619\left(\mathrm{M}^{+}-\mathrm{PPh}_{3}\right), 431\left(\mathrm{M}^{+}-\mathrm{PPh}_{3}, \mathrm{C}_{2} \mathrm{PhCH}_{2^{-}}\right.$ COOEt). Anal. Calcd for $\mathrm{C}_{53} \mathrm{H}_{47} \mathrm{O}_{2} \mathrm{P}_{3} \mathrm{~F}_{6} \mathrm{Ru}$ : C, 62.17; H, 4.63. Found: C, 62.62; H, 4.50.

Synthesis of $\left[[\mathbf{R u}]=\mathbf{C}=\mathbf{C}(\mathbf{P h}) \mathbf{C H}_{2} \mathbf{O C H}_{3}\right]\left[\mathrm{PF}_{6}\right](\mathbf{2 j})$. The synthetic procedure was similar to that used for the preparation of $\mathbf{2 b}$ : A solution of $1 \mathrm{a}(0.923 \mathrm{~g}, 1.16 \mathrm{mmol})$ in $20 \mathrm{~mL}$ of $\mathrm{CH}_{2} \mathrm{Cl}_{2}, \mathrm{ICH}_{2} \mathrm{OCH}_{3}(0.15$ $\mathrm{mL}, 1.17 \mathrm{mmol}$ ) (Caution: Free $\mathrm{ICH}_{2} \mathrm{OCH}_{3}$ is a potential carcinogen), and $\mathrm{NH}_{4} \mathrm{PF}_{6}(0.27 \mathrm{~g}, 1.66 \mathrm{mmol})$ were used. The reaction was completed immediately upon mixing of the reactants. The product was recrystallized from $\mathrm{CH}_{2} \mathrm{Cl}_{2} /$ hexane (1:5) and identified as $2 \mathbf{j}(0.87 \mathrm{~g}$, $0.88 \mathrm{mmol}, 76 \%)$. Spectroscopic data of $\mathbf{2 \mathbf { j }}:{ }^{1} \mathrm{H} \mathrm{NMR} \mathrm{CD}_{3} \mathrm{CN}: 7.93-$ $6.94(\mathrm{Ph}) ; 5.32$ (s, 5H, Cp); $3.95\left(\mathrm{~s}, 2 \mathrm{H}, \mathrm{CH}_{2}\right) ; 3.09\left(\mathrm{~s}, 3 \mathrm{H}, \mathrm{CH}_{3}\right) .{ }^{13} \mathrm{C}$

(55) Bruce, M. I.; Hinterding, P.; Tiekink, E. R. T.; Skeleton, B. W.; White, A. H. J. Organomet. Chem. 1993, 450, 209.

(56) Bruce, M. I.; Humphrey, M. G. Aust. J. Chem. 1989, 42, 1067. 
NMR $\mathrm{CD}_{3} \mathrm{CN}: 348.5\left(\mathrm{t}, J_{\mathrm{C}-\mathrm{P}}=16.1 \mathrm{~Hz}, \mathrm{C}_{\alpha}\right) ; 135.9-128.8(\mathrm{Ph}) ; 118.2$ $\left(\mathrm{C}_{\beta}\right)$; $95.7(\mathrm{Cp}) ; 67.5\left(\mathrm{CH}_{3}\right) ; 57.8\left(\mathrm{CH}_{2}\right)$. ${ }^{31} \mathrm{P} \mathrm{NMR} \mathrm{CD} \mathrm{CNN}_{3}: 42.5(\mathrm{~s})$. MS FAB m/z: $839\left(\mathrm{M}^{+}\right), 577\left(\mathrm{M}^{+}-\mathrm{PPh}_{3}\right), 431\left(\mathrm{M}^{+}-\mathrm{PPh}_{3}, \mathrm{C}_{2^{-}}\right.$ $\mathrm{PhCH}_{2} \mathrm{OMe}$ ). Anal. Calcd for $\mathrm{C}_{51} \mathrm{H}_{45} \mathrm{OP}_{3} \mathrm{~F}_{6} \mathrm{Ru}$ : C, 62.38; H, 4.62. Found: C, 62.11; H, 4.98.

Complex $\left[[\mathrm{Ru}]=\mathrm{C}=\mathrm{C}\left(\mathrm{C}_{6} \mathrm{H}_{9}\right) \mathrm{CH}_{2} \mathrm{CN}\right] \mathrm{I}(\mathbf{2 k})(0.80 \mathrm{~g}, 0.82 \mathrm{mmol}, 75 \%$ yield) was prepared from $1 \mathbf{k}(0.87 \mathrm{~g}, 1.09 \mathrm{mmol})$ and $\mathrm{ICH}_{2} \mathrm{CN}$ using the same procedure as for $\mathbf{2} \mathbf{b}$. Spectroscopic data of $\mathbf{2 k}$ : ${ }^{1} \mathrm{H}$ NMR $\mathrm{CDCl}_{3}$ : 7.44-6.96 (m, 30H, Ph); $5.77(\mathrm{br}, 1 \mathrm{H},=\mathrm{CH}) ; 5.18(\mathrm{~s}, 5 \mathrm{H}$, $\mathrm{Cp}$ ); 2.85 (s, 2H, $\mathrm{CH}_{2} \mathrm{CN}$ ); 2.15, 1.84, 1.62, 1.53 (br, $\left.8 \mathrm{H}, 4 \mathrm{CH}_{2}\right) .{ }^{13} \mathrm{C}$ $\mathrm{NMR} \mathrm{CDCl}_{3}: 349.0\left(\mathrm{t}, \mathrm{br}, \mathrm{C}_{\alpha}\right) ; 134.4-128.8(\mathrm{Ph}) ; 125.0\left(\mathrm{CH}\right.$ of $\left.\mathrm{C}_{6} \mathrm{H}_{9}\right)$; $124.2\left(\mathrm{C}_{\beta}\right) ; 118.5(\mathrm{CN}) ; 95.0(\mathrm{Cp}) ; 30.9,28.0,22.8,21.6\left(4 \mathrm{CH}_{2}\right) ; 12.7$ $\left(\mathrm{CH}_{2} \mathrm{CN}\right)$. ${ }^{31} \mathrm{P} \mathrm{NMR} \mathrm{CDCl} \mathrm{NM}_{3}: 41.1$ (s). MS FAB $\mathrm{m} / \mathrm{z}: 836\left(\mathrm{M}^{+}\right), 574$ $\left(\mathrm{M}^{+}-\mathrm{PPh}_{3}\right), 431\left(\mathrm{M}^{+}-\mathrm{C}_{2}\left(\mathrm{C}_{6} \mathrm{H}_{9}\right) \mathrm{CH}_{2} \mathrm{CN}\right)$.

Synthesis of $[\mathbf{R u}] \mathbf{C}=\mathbf{C}(\mathbf{P h}) \mathbf{C}(\mathbf{C N}) \mathbf{H}(\mathbf{3 b})$. To a solution of $\mathbf{2 b}(0.40$ $\mathrm{g}, 0.41 \mathrm{mmol})$ in $15 \mathrm{~mL}$ of acetone was added a solution of $n-\mathrm{Bu}_{4}$ $\mathrm{NOH}(4.5 \mathrm{~mL}, 1 \mathrm{M}$ in $\mathrm{MeOH})$. The mixture was stirred overnight yielding the light yellow microcrystalline precipitate which was filtered off and washed with $2 \times 5 \mathrm{~mL}$ of acetone, $2 \times 10 \mathrm{~mL}$ of diethyl ether, and $10 \mathrm{~mL}$ of $\mathrm{n}$-hexane, then dried under vacuum. The product was analytically pure and was identified as $\mathbf{3 b}(0.27 \mathrm{~g}, 0.33 \mathrm{mmol}, 80 \%)$. When $\mathbf{2 b}$ was treated with $n-\mathrm{Bu}_{4} \mathrm{NF}$ ( $1 \mathrm{M}$ in THF) or DBU, instead of $n-\mathrm{Bu}_{4} \mathrm{NOH}$, the same product was obtained. Single crystals suitable for X-ray diffraction analysis were grown from the same reaction mixture with lower concentration. Spectroscopic data of 3b: ${ }^{1} \mathrm{H}$ NMR $\mathrm{CDCl}_{3}: 7.20-6.61(\mathrm{~m}, 35 \mathrm{H}, \mathrm{Ph}) ; 4.54(\mathrm{~s}, 5 \mathrm{H}, \mathrm{Cp}) ; 1.40$ (s, 1H, CH). ${ }^{13} \mathrm{C} \mathrm{NMR} \mathrm{CDCl}_{3}: 134.8-128.4(\mathrm{Ph}) ; 126.2\left(\mathrm{t}, J_{\mathrm{C}-\mathrm{P}}=23.0 \mathrm{~Hz}, \mathrm{C}_{\alpha}\right)$; $113.8(\mathrm{CN}) ; 86.3(\mathrm{Cp}) ; 7.96(\mathrm{CH}) .{ }^{31} \mathrm{P} \mathrm{NMR} \mathrm{CDCl}{ }_{3}: 51.7,49.6(\mathrm{AB}$, $\left.J_{\mathrm{P}-\mathrm{P}}=34.6 \mathrm{~Hz}\right)$. MS FAB $m / z: 834\left(\mathrm{M}^{+}+1\right), 572\left(\mathrm{M}^{+}-\mathrm{PPh}_{3}\right)$, $430\left(\mathrm{M}^{+}-\mathrm{PPh}_{3}, \mathrm{C}_{2} \mathrm{PhCHCN}\right)$. Anal. Calcd for $\mathrm{C}_{51} \mathrm{H}_{41} \mathrm{NP}_{2} \mathrm{Ru}: \mathrm{C}$, 73.72; H, 4.97; N, 1.69. Found: C, 73.63; H, 4.55; N, 1.42.

Synthesis of $[\mathbf{R u}]-\mathbf{C}=\mathbf{C}(\mathbf{P h}) \mathbf{C}(\mathbf{P h}) \mathbf{H}(\mathbf{3 c})$. Complex $\mathbf{3 c}(0.14 \mathrm{~g}$, $0.16 \mathrm{mmol}, 55 \%$ yield $)$ was similarly prepared from $2 \mathrm{c}(0.30 \mathrm{~g}, 0.29$ mmol) and $n-\mathrm{Bu}_{4} \mathrm{NOH}(3.0 \mathrm{~mL})$ in $15 \mathrm{~mL}$ of acetone. Spectroscopic data for 3c: ${ }^{1} \mathrm{H}$ NMR $\mathrm{CDCl}_{3}: 8.19-6.61(\mathrm{~m}, 40 \mathrm{H}, \mathrm{Ph}), 4.22(\mathrm{~s}, 5 \mathrm{H}$, Cp), 2.54 (s, 1H, CH). ${ }^{13} \mathrm{C} \mathrm{NMR} \mathrm{CDCl}_{3}: 140.8-119.3(\mathrm{Ph}), 137.7$ (t, $\left.J_{\mathrm{C}-\mathrm{P}}=19.7 \mathrm{~Hz}, \mathrm{C}_{\alpha}\right), 85.2(\mathrm{Cp}), 32.9(\mathrm{CH}) .{ }^{31} \mathrm{P} \mathrm{NMR} \mathrm{CDCl}_{3}$ : 54.7, $47.8\left(\mathrm{~d}, J_{\mathrm{P}-\mathrm{P}}=34.9 \mathrm{~Hz}, 2 \mathrm{PPh}_{3}\right)$. MS FAB $\mathrm{m} / z: 885\left(\mathrm{M}^{+}\right), 721\left(\mathrm{M}^{+}\right.$ $\left.+\mathrm{CO}-\mathrm{C}_{15} \mathrm{H}_{11}\right), 693\left(\mathrm{M}^{+}-\mathrm{C}_{15} \mathrm{H}_{11}\right)$. Anal. Calcd for $\mathrm{C}_{56} \mathrm{H}_{46} \mathrm{P}_{2} \mathrm{Ru}$ : C, 76.26; H, 5.26. Found: C, 76.56; H, 4.98.

Synthesis of $[\mathbf{R u}]-\mathbf{C}=\mathbf{C}(\mathbf{P h}) \mathbf{C}\left(\mathbf{C}_{2} \mathbf{H}_{3}\right) \mathbf{H}$ (3d). Complex 3d was similarly prepared from $2 \mathbf{d}(0.44 \mathrm{~g}, 0.45 \mathrm{mmol})$ and $5.0 \mathrm{~mL}$ of $n$-Bu $4^{-}$ $\mathrm{NOH}$ in $10 \mathrm{~mL}$ of acetone. The product was obtained in $53 \%$ yield $(0.20 \mathrm{~g}, 0.24 \mathrm{mmol})$. Spectroscopic data for $3 \mathrm{~d}$ : ${ }^{1} \mathrm{H}$ NMR $\mathrm{CDCl}_{3}$ : $7.45-6.63(\mathrm{~m}, 35 \mathrm{H}, \mathrm{Ph}), 5.84\left(\mathrm{ddd}, J_{\mathrm{H}-\mathrm{H}}=17.0,10.1,9.2 \mathrm{~Hz}, 1 \mathrm{H}\right.$, $=\mathrm{CH}), 5.24\left(\mathrm{dd}, J_{\mathrm{H}-\mathrm{H}}=17.0,2.5 \mathrm{~Hz}, 1 \mathrm{H}\right.$ of $\left.=\mathrm{CH}_{2}\right), 4.78,\left(\mathrm{dd}, J_{\mathrm{H}-\mathrm{H}}\right.$ $=10.1,2.5 \mathrm{~Hz}, 1 \mathrm{H}$ of $\left.=\mathrm{CH}_{2}\right), 4.49(\mathrm{~s}, 5 \mathrm{H}, \mathrm{Cp}), 2.02\left(\mathrm{~d}, 1 \mathrm{H}, J_{\mathrm{H}-\mathrm{H}}=\right.$ $9.2 \mathrm{~Hz}, \mathrm{CH}) .{ }^{13} \mathrm{C} \mathrm{NMR} \mathrm{CDCl} 3: 153.8(=\mathrm{CH}), 138.4\left(\mathrm{t}, J_{\mathrm{C}-\mathrm{P}}=19.3\right.$ $\left.\mathrm{Hz}, \mathrm{C}_{\alpha}\right), 135.5-123.7(\mathrm{Ph}), 105.9\left(=\mathrm{CH}_{2}\right), 85.7(\mathrm{Cp}), 32.8(\mathrm{CH}) .{ }^{31} \mathrm{P}$ $\mathrm{NMR} \mathrm{CDCl}_{3}: 53.2,49.9\left(\mathrm{AB}, J_{\mathrm{P}-\mathrm{P}}=35.5 \mathrm{~Hz}, 2 \mathrm{PPh}_{3}\right)$. MS FAB $m / z: 835\left(\mathrm{M}^{+}+1\right), 795\left(\mathrm{M}^{+}+1-\mathrm{C}_{3} \mathrm{H}_{4}\right), 721\left(\mathrm{M}^{+}+\mathrm{CO}-\mathrm{C}_{11} \mathrm{H}_{9}\right)$, $693\left(\mathrm{M}^{+}-\mathrm{C}_{11} \mathrm{H}_{9}\right), 431\left(\mathrm{M}^{+}-\mathrm{C}_{11} \mathrm{H}_{9}, \mathrm{PPh}_{3}\right)$. Anal. Calcd for $\mathrm{C}_{52} \mathrm{H}_{44} \mathrm{P}_{2^{-}}$ $\mathrm{Ru}:$ C, 75.07; H, 5.33. Found: C, 75.01; H, 5.22.

Synthesis of $[\mathbf{R u}]-\mathbf{C}=\mathbf{C}(\mathbf{P h}) \mathbf{C}\left(\mathbf{C H}=\mathbf{C M e}_{2}\right) \mathbf{H}(3 \mathbf{e})$. Complex $3 \mathbf{e}$ in $48 \%$ yield $(0.17 \mathrm{~g}, 0.20 \mathrm{mmol})$ was similarly prepared from $2 \mathbf{e}(0.43$ $\mathrm{g}, 0.41 \mathrm{mmol})$ in $10 \mathrm{~mL}$ of acetone and $n-\mathrm{Bu}_{4} \mathrm{NOH}(4.5 \mathrm{~mL})$. Spectroscopic data for 3e: ${ }^{1} \mathrm{H}$ NMR $\mathrm{CDCl}_{3}$ : $7.61-6.62(\mathrm{~m}, 35 \mathrm{H}, \mathrm{Ph})$, $4.94\left(\mathrm{~d}, J_{\mathrm{H}-\mathrm{H}}=9.4 \mathrm{~Hz}, 1 \mathrm{H}, \mathrm{CH}\right), 4.39(\mathrm{~s}, 5 \mathrm{H}, \mathrm{Cp}), 1.94\left(\mathrm{~d}, 1 \mathrm{H}, J_{\mathrm{H}-\mathrm{H}}\right.$ $=9.4 \mathrm{~Hz},=\mathrm{CH}) ; 1.89,1.70\left(\mathrm{~s}, 2 \mathrm{CH}_{3}\right) .{ }^{31} \mathrm{P} \mathrm{NMR} \mathrm{CDCl} \mathrm{N}_{3}: 53.0,50.2$ $\left(\mathrm{d}, J_{\mathrm{P}-\mathrm{P}}=35.7 \mathrm{~Hz}, 2 \mathrm{PPh}_{3}\right)$. MS FAB $m / z: 863\left(\mathrm{M}^{+}+1\right), 601\left(\mathrm{M}^{+}\right.$ $\left.+1-\mathrm{PPh}_{3}\right), 431\left(\mathrm{M}^{+}-\mathrm{C}_{13} \mathrm{H}_{13}, \mathrm{PPh}_{3}\right)$. Anal. Calcd for $\mathrm{C}_{54} \mathrm{H}_{48} \mathrm{P}_{2} \mathrm{Ru}$ : C, 75.42; H, 5.63. Found: C, 75.23; H, 5.87. Protonation of $\mathbf{3 b}$ by $\mathrm{CF}_{3} \mathrm{COOH}$ in $\mathrm{CDCl}_{3}$ was carried out in a NMR tube and the reaction cleanly yielded $\mathbf{2 b}$. The yield is $>95 \%$ based on the integration of the $\mathrm{Cp}$ resonances relative to an internal standard. Similarly protonation of $\mathbf{3 c}, \mathbf{3 d}$, and $\mathbf{3 e}$ gave $\mathbf{2 c}, \mathbf{2 d}$, and $\mathbf{2 e}$, respectively, all with $>95 \%$ NMR yields.

Synthesis of $[\mathbf{R u}] \mathbf{C}=\mathbf{C}\left(\mathbf{C}_{6} \mathbf{H}_{9}\right) \mathbf{C}(\mathbf{C N}) \mathbf{H}$ (3k). The cyclopropenyl complex with a cyclohexenyl group on the $\mathrm{C}_{\beta}$ was soluble in acetone thus a slightly modified procedure is used. To a solution of $\mathbf{2 k}(0.45$ $\mathrm{g}, 0.47 \mathrm{mmol}$ ) in $15 \mathrm{~mL}$ of acetone was added a solution of $\mathrm{n}-\mathrm{Bu}_{4}-$ NOH $(2.0 \mathrm{~mL})$. The solution was stirred for $3 \mathrm{~h}$. Then the workup procedure was the same as that for $\mathbf{3 b}$. This product was identified as 3k $(0.30 \mathrm{~g}, 0.36 \mathrm{mmol}, 77 \%$ yield) which gave $2 \mathbf{k}$ quantitatively in the presence of $\mathrm{MeOH}$. Replacing $n-\mathrm{Bu}_{4} \mathrm{NOH}$ by $n-\mathrm{Bu}_{4} \mathrm{NF}$ or DBU gave the same product with slightly lower yield. Spectroscopic data for $3 \mathrm{k}$ : ${ }^{1} \mathrm{H}$ NMR $\mathrm{CDCl}_{3}$ : 7.44-6.97 (m, 30H, $\left.\mathrm{Ph}\right), 5.41(\mathrm{t}, \mathrm{br}, 1 \mathrm{H}$, $=\mathrm{CH}), 4.53(\mathrm{~s}, 5 \mathrm{H}, \mathrm{Cp}) ; 2.01,1.63,1.43,1.35\left(\mathrm{br}, 4 \mathrm{CH}_{2}\right) ; 1.08(\mathrm{~s}$, $1 \mathrm{H}, \mathrm{CHCN}) .{ }^{13} \mathrm{C}$ NMR $\mathrm{CDCl}_{3}: 140.0-127.0(\mathrm{Ph}), 126.2(=\mathrm{CH}$ in $\left.\mathrm{C}_{6} \mathrm{H}_{9}\right), 116.2(\mathrm{CN}), 86.0(\mathrm{Cp}), 26.9,25.6,22.8,22.3\left(\mathrm{CH}_{2}\right.$ in $\left.\mathrm{C}_{6} \mathrm{H}_{9}\right)$, $7.7(C \mathrm{HCN}) .{ }^{31} \mathrm{P} \mathrm{NMR} \mathrm{CDCl}{ }_{3}: 51.7,49.0\left(\mathrm{AB}, J_{\mathrm{P}-\mathrm{P}}=36.4 \mathrm{~Hz}, 2\right.$ $\left.\mathrm{PPh}_{3}\right)$. MS FAB $m / z: 838\left(\mathrm{M}^{+}+1\right), 693\left(\mathrm{M}^{+}-\right.$cyclopropenyl moiety), $576\left(\mathrm{M}^{+}+1-\mathrm{PPh}_{3}\right), 431\left(\mathrm{M}^{+}-\right.$cyclopropenyl moiety, $\mathrm{PPh}_{3}$ ). Anal. Calcd for $\mathrm{C}_{54} \mathrm{H}_{48} \mathrm{P}_{2} \mathrm{Ru}: \mathrm{C}, 75.42 ; \mathrm{H}, 5.63$. Found: $\mathrm{C}$, 75.23; H, 5.87.

Synthesis of $\left[[\mathbf{R u}]=\mathbf{C}=\mathbf{C}(\mathbf{P h}) \mathbf{C H}(\mathbf{C N}) \mathbf{C P h}_{3}\right]\left[\mathbf{P F}_{\mathbf{6}}\right](\mathbf{2 f})$. To a solid mixture of $\mathbf{3 b}(0.76 \mathrm{~g}, 0.91 \mathrm{mmol})$ and $\mathrm{Ph}_{3} \mathrm{CPF}_{6}(0.36 \mathrm{~g}, 0.93 \mathrm{mmol})$ at $0{ }^{\circ} \mathrm{C}$ was added by syringe $25 \mathrm{~mL}$ of $\mathrm{CH}_{2} \mathrm{Cl}_{2}$. The mixture was stirred for $40 \mathrm{~min}$, and then the solvent was removed under vacuum. The residue which contained $\mathbf{2 f}$ and $\mathbf{2 b}$ was washed with $3 \times 20 \mathrm{~mL}$ of benzene to remove $\mathbf{2 b}$ then with $2 \times 10 \mathrm{~mL}$ of diethyl ether and dried to give $2 \mathrm{f}(0.71 \mathrm{~g}, 0.58 \mathrm{mmol}, 64 \%)$. The solvent of a portion of $\mathbf{2 b}$ was removed and the residue was redissolved in $\mathrm{CH}_{2} \mathrm{Cl}_{2}$ and poured into a stirred diethyl ether to give $2 \mathbf{b}(0.20 \mathrm{~g}, 0.21 \mathrm{mmol}, 28 \%$ yield). Spectroscopic data of $2 \mathbf{f}$ : ${ }^{1} \mathrm{H}$ NMR $\mathrm{CD}_{3} \mathrm{CN}$ : $7.49-6.58(\mathrm{Ph})$; 5.29 (s, $5 \mathrm{H}, \mathrm{Cp}) ; 5.03(\mathrm{~s}, 1 \mathrm{H}, \mathrm{CH}) .{ }^{13} \mathrm{C} \mathrm{NMR} \mathrm{CD}{ }_{3} \mathrm{CN}: 340.3$ (t, $J_{\mathrm{C}-\mathrm{P}}$ $\left.=16.5 \mathrm{~Hz}, \mathrm{C}_{\alpha}\right) ; 135.9-128.8(\mathrm{Ph}) ; 125.3\left(\mathrm{C}_{\beta}\right) ; 122.6(\mathrm{CN}) ; 96.2(\mathrm{Cp})$; $60.1\left(\mathrm{CPh}_{3}\right) ; 36.0(\mathrm{CH}) .{ }^{31} \mathrm{P} \mathrm{NMR} \mathrm{CD} \mathrm{CN}_{3}: 41.3,38.6\left(\mathrm{~d}, J_{\mathrm{P}-\mathrm{P}}=26.5\right.$ Hz). MS FAB m/z: $1076\left(\mathrm{M}^{+}\right), 834\left(\mathrm{M}^{+}-\mathrm{CPh}_{3}\right), 571\left(\mathrm{M}^{+}-\right.$ $\mathrm{CPh}_{3}, \mathrm{PPh}_{3}$ ). Anal. Calcd for $\mathrm{C}_{70} \mathrm{H}_{56} \mathrm{NP}_{3} \mathrm{~F}_{6} \mathrm{Ru}: \mathrm{C}, 68.96 ; \mathrm{H}, 4.63 ; \mathrm{N}$, 1.15. Found: $\mathrm{C}, 68.70 ; \mathrm{H}, 5.03 ; \mathrm{N}, 1.09$.

Synthesis of $[[\mathbf{R u}]=\mathbf{C}=\mathbf{C}(\mathbf{P h}) \mathbf{C H}(\mathbf{C N}) \mathbf{H g C l}] \mathbf{C l}(\mathbf{2 g})$. To a mixture of $\mathbf{3 b}(0.47 \mathrm{~g}, 0.56 \mathrm{mmol})$ and $\mathrm{HgCl}_{2}(0.19 \mathrm{~g}, 0.70 \mathrm{mmol})$ at $0{ }^{\circ} \mathrm{C}$ was added by syringe $25 \mathrm{~mL}$ of $\mathrm{CH}_{2} \mathrm{Cl}_{2}$. The mixture was stirred for 40 min. The workup procedure was the same as that in $\mathbf{2} \mathbf{f}$ and no $\mathbf{2 b}$ was observed. The product identified as $\mathbf{2} \mathbf{g}$ was obtained $(0.55 \mathrm{~g}, 0.45$ mmol, 81\%). Spectroscopic data for $2 \mathrm{~g}$ : ${ }^{1} \mathrm{H}$ NMR $\mathrm{CDCl}_{3}$ : 7.45$6.76(\mathrm{~m}, 35 \mathrm{H}, \mathrm{Ph}), 5.32(\mathrm{~s}, 5 \mathrm{H}, \mathrm{Cp}), 3.62(\mathrm{~s}, 1 \mathrm{H}, \mathrm{CH}) .{ }^{13} \mathrm{C}$ NMR $\mathrm{CDCl}_{3}: 344.3\left(\mathrm{t}, J_{\mathrm{C}-\mathrm{P}}=13.1 \mathrm{~Hz}, \mathrm{C}_{\alpha}\right), 134.5-127.1(\mathrm{Ph}), 125.2\left(\mathrm{C}_{\beta}\right)$, $120.9(\mathrm{CN}), 95.2(\mathrm{Cp}), 26.2(\mathrm{CH}) .{ }^{31} \mathrm{P} \mathrm{NMR} \mathrm{CD} \mathrm{CN}_{3} \mathrm{C}: 42.4,40.3(\mathrm{AB}$, $\left.J_{\mathrm{P}-\mathrm{P}}=26.4 \mathrm{~Hz}, 2 \mathrm{PPh}_{3}\right) . \mathrm{MS} \mathrm{FAB} m / z: 1070\left(\mathrm{M}^{+}\right), 833\left(\mathrm{M}^{+}-\mathrm{HgCl}\right)$, $693\left(\mathrm{M}^{+}-\mathrm{HgCl}, \mathrm{C}_{2} \mathrm{PhCHCN}\right), 571\left(\mathrm{M}^{+}-\mathrm{HgCl}, \mathrm{PPh}_{3}\right)$.

Reaction of $2 \mathrm{~h}$ with $\mathrm{Bu}_{4} \mathrm{NOH}$. To a suspension of complex $2 \mathrm{~h}$ $(0.94 \mathrm{~g}, 0.93 \mathrm{mmol})$ in $15 \mathrm{~mL}$ of acetone at room temperature was added a $2.5-\mathrm{mL}$ solution of $n-\mathrm{Bu}_{4} \mathrm{OH}$. The solution gave orange precipitate after being stirred overnight. The precipitate was filtered and washed with $10 \mathrm{~mL}$ of $\mathrm{MeOH}, 2 \times 5 \mathrm{~mL}$ of acetone, and $10 \mathrm{~mL}$ of hexane and then dried under vacuum. Recrystallization from a

mixture of $\mathrm{C}_{6} \mathrm{H}_{12} / \mathrm{CHCl}_{3}(1: 1)$ yielded $[\mathrm{Ru}]-\mathrm{C}=\mathrm{C}(\mathrm{Ph}) \mathrm{CH}=\mathrm{C}(\mathrm{O}) \mathrm{OCH}_{3}$ (4h) $\left(0.64 \mathrm{~g}, 0.74 \mathrm{mmol}, 80 \%\right.$ yield). Spectroscopic data for $\mathbf{4 h}$ : ${ }^{1} \mathrm{H}$ NMR CDCl $: 7.32-6.97(\mathrm{~m}, 35 \mathrm{H}, \mathrm{Ph}) ; 4.92(\mathrm{~s}, 1 \mathrm{H}, \mathrm{CH}) ; 4.05(\mathrm{~s}, 5 \mathrm{H}$, $\mathrm{Cp}) ; 3.04\left(\mathrm{~s}, 3 \mathrm{H}, \mathrm{CH}_{3}\right) .{ }^{13} \mathrm{C} \mathrm{NMR} \mathrm{CDCl}_{3}: 164.0\left(\mathrm{CO}_{2}\right) ; 154.6\left(\mathrm{t}, J_{\mathrm{C}-\mathrm{P}}\right.$ $\left.=19.0 \mathrm{~Hz}, \mathrm{C}_{\alpha}\right) ; 140.5-125.3(\mathrm{Ph}) ; 86.6\left(\mathrm{C}_{\gamma}\right) ; 83.9(\mathrm{Cp}) ; 58.0\left(\mathrm{CH}_{3}\right)$. ${ }^{31} \mathrm{P} \mathrm{NMR} \mathrm{CDCl} \mathrm{N}_{3}: 51.3$ (s). MS FAB $m / z: 867\left(\mathrm{M}^{+}+1\right), 721\left(\mathrm{M}^{+}-\right.$ $\left.\mathrm{C}_{2} \mathrm{PhCH}\left(\mathrm{CO}_{2} \mathrm{Me}\right)+\mathrm{CO}\right), 693\left(\mathrm{M}^{+}-\mathrm{C}_{2} \mathrm{PhCH}\left(\mathrm{CO}_{2} \mathrm{Me}\right)\right), 431\left(\mathrm{M}^{+}-\right.$ $\left.\mathrm{C}_{2} \mathrm{PhCH}\left(\mathrm{CO}_{2} \mathrm{Me}\right), \mathrm{PPh}_{3}\right)$. Anal. Calcd for $\mathrm{C}_{52} \mathrm{H}_{44} \mathrm{O}_{2} \mathrm{P}_{2} \mathrm{Ru}$ : C, 72.29; H, 5.13. Found: C, 74.49; H, 5.75 (the deviation might be due to the solvent trapped in the solid during recrystallization).

When the same reaction was carried out at $5{ }^{\circ} \mathrm{C},[\mathrm{Ru}]-\mathrm{C}=\mathrm{C}$ $\overrightarrow{(\mathrm{Ph})} \mathrm{CH}=\mathrm{COOCH}_{3}(\mathbf{3 h})$ and 1a with a ratio of $2: 1$ were isolated in $75 \%$ total yield. At this temperature, $4 \mathrm{~h}$ was not observed. No attempt was made to separate $\mathbf{3 h}$ and 1a. Spectroscopic data of $\mathbf{3 h}:{ }^{1} \mathrm{H}$ NMR $\mathrm{CDCl}_{3}$ : 7.50-6.54 (m, 35H, Ph); 4.40 (s, 5H, Cp); $3.72\left(\mathrm{~s}, 3 \mathrm{H}, \mathrm{CH}_{3}\right)$; $2.12(\mathrm{~s}, 1 \mathrm{H}, \mathrm{CH}) .{ }^{31} \mathrm{P} \mathrm{NMR} \mathrm{CDCl}{ }_{3}: 52.7,48.0\left(\mathrm{AB}, J_{\mathrm{P}-\mathrm{P}}=35.5 \mathrm{~Hz}\right)$. Complex $3 \mathbf{h}$ was completely converted to $\mathbf{4 h}$ in $\mathrm{CDCl}_{3}$ at room temperature for $4 \mathrm{~h}$.

Complex $[\mathrm{Ru}]-\mathrm{C}=\mathrm{C}(\mathrm{Ph}) \mathrm{CH}=\mathrm{C}(\mathrm{O}) \mathrm{OEt}(\mathbf{4 i})(0.301 \mathrm{~g}, 0.340 \mathrm{mmol})$ was similarly prepared from $2 \mathbf{i}(0.450 \mathrm{~g}, 0.440 \mathrm{mmol}, 78 \%$ yield $)$ and $n$-Bu $\mathrm{BuH}_{4} \mathrm{NOH}$ Spectroscopic data for $4 \mathrm{i}$ : ${ }^{1} \mathrm{H} \mathrm{NMR} \mathrm{CDCl}_{3}$ : $7.34-6.91$ 
$(\mathrm{m}, 35 \mathrm{H}, \mathrm{Ph}) ; 4.96(\mathrm{~s}, 1 \mathrm{H}, \mathrm{CH}) ; 4.05(\mathrm{~s}, 5 \mathrm{H}, \mathrm{Cp}) ; 3.09\left(\mathrm{q}, J_{\mathrm{H}-\mathrm{H}}=7.01\right.$ $\left.\mathrm{Hz}, 2 \mathrm{H}, \mathrm{OCH}_{2}\right) ; 0.91\left(\mathrm{t}, J_{\mathrm{H}-\mathrm{H}}=7.01 \mathrm{~Hz}, 3 \mathrm{H}, \mathrm{CH}_{3}\right) .{ }^{13} \mathrm{C} \mathrm{NMR}$ $\mathrm{CDCl}_{3}: 162.7\left(\mathrm{~s}, \mathrm{CO}_{2}\right) ; 154.7\left(J_{\mathrm{P}-\mathrm{C}}=17.5 \mathrm{~Hz}, \mathrm{C}_{\alpha}\right) ; 142.3-125.2(\mathrm{Ph})$; $88.6\left(\mathrm{CHCO}_{2}\right) ; 83.8(\mathrm{Cp}) ; 66.7\left(\mathrm{OCH}_{2}\right) ; 14.8\left(\mathrm{CH}_{3}\right) .{ }^{31} \mathrm{P}$ NMR $\mathrm{CDCl}_{3}: 51.2$ (s). MS FAB $m / z: 880\left(\mathrm{M}^{+}\right), 721\left(\mathrm{M}^{+}+\mathrm{CO}-\mathrm{C}_{2^{-}}\right.$ PhCHCOOEt), $693\left(\mathrm{M}^{+}-\mathrm{C}_{2} \mathrm{PhCHCOOEt}\right), 431\left(\mathrm{M}^{+}-\mathrm{PPh}_{3}, \mathrm{C}_{2^{-}}\right.$ PhCHCOOEt). Anal. Calcd for $\mathrm{C}_{53} \mathrm{H}_{46} \mathrm{O}_{2} \mathrm{P}_{2} \mathrm{Ru}$ : C, 72.50; H, 5.28. Found: C, 72.34; H, 5.10.

Reaction of $2 f$ with $\boldsymbol{n}$-BuN $\mathbf{N}_{4} \mathbf{F}$. To a solution of $2 \mathrm{f}(0.35 \mathrm{~g}, 0.29$ $\mathrm{mmol}$ ) in $10 \mathrm{~mL}$ of acetone, was added a $3.5-\mathrm{mL}$ solution of $n$-Bu $\mathrm{Bu}_{4} \mathrm{NF}$. After for $48 \mathrm{~h}$, the light yellow microcrystals formed and were filtered and washed with $2 \times 10 \mathrm{~mL}$ of diethyl ether and then dried under

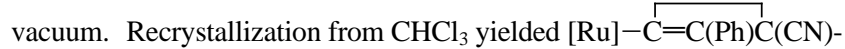
$\mathrm{CPh}_{3}$ (3f) $(0.12 \mathrm{~g}, 0.11 \mathrm{mmol}, 38 \%$ yield). Spectroscopic data for $\mathbf{3 f}$ : ${ }^{1} \mathrm{H} \mathrm{NMR} \mathrm{CDCl}{ }_{3}: 7.79-5.47$ (m, 50H, Ph); 4.29 (s, 5H, Cp). ${ }^{13} \mathrm{C} \mathrm{NMR}$ $\mathrm{CDCl}_{3}$ : $142.0-125.0(\mathrm{Ph}) ; 121.1(\mathrm{CN}) ; 84.6(\mathrm{Cp}) ; 62.1\left(\mathrm{CPh}_{3}\right) ; 37.5$ $(C \mathrm{CN}) .{ }^{31} \mathrm{P} \mathrm{NMR} \mathrm{CDCl}_{3}: 47.0,46.7\left(\mathrm{~d}, J_{\mathrm{P}-\mathrm{P}}=35.6 \mathrm{~Hz}\right) . \quad \mathrm{MS}$ FAB $m / z: 1077\left(\mathrm{M}^{+}+1\right), 814\left(\mathrm{M}^{+}-\mathrm{PPh}_{3}\right), 693\left(\mathrm{M}^{+}-\mathrm{C}_{3} \mathrm{Ph}(\mathrm{CN}) \mathrm{CPh}_{3}\right)$. Anal. Calcd for $\mathrm{C}_{70} \mathrm{H}_{55} \mathrm{NP}_{2} \mathrm{Ru}$ : C, 78.34; H, 5.17; N, 1.31. Found: C, 78.67; H, 5.15; N, 1.72 .

Reaction of Complex $2 \mathbf{j}$ with $\boldsymbol{n}-\mathbf{B u}_{\mathbf{4}} \mathbf{N F}$. The synthesis and workup were similar to those used in the preparation of complex $4 \mathbf{h}$, but a solution of $2 \mathbf{j}(0.34 \mathrm{~g}, 0.35 \mathrm{mmol})$ in $10 \mathrm{~mL}$ of acetone and a solution of $n-\mathrm{Bu}_{4} \mathrm{NF}(4 \mathrm{~mL})$ were used yielding $[\mathrm{Ru}]-\mathrm{CF}=\mathrm{C}(\mathrm{Ph}) \mathrm{CH}_{2} \mathrm{OCH}_{3}(\mathbf{5})$ $\left(0.24 \mathrm{~g}, 0.28 \mathrm{mmol}, 80 \%\right.$ yield). Spectroscopic data for 5: ${ }^{1} \mathrm{H}$ NMR $-40{ }^{\circ} \mathrm{C}, \mathrm{CDCl}_{3}: 7.47-6.88(\mathrm{Ph}) ; 4.00\left(\mathrm{br}, \mathrm{s}, 2 \mathrm{H}, \mathrm{CH}_{2}\right) ; 3.78(\mathrm{~s}, 5 \mathrm{H}$, $\mathrm{Cp}) ; 3.05$ (s, $\left.3 \mathrm{H}, \mathrm{CH}_{3}\right) .{ }^{13} \mathrm{C} \mathrm{NMR}-40{ }^{\circ} \mathrm{C}, \mathrm{CDCl}_{3}: 133.4-125.8(\mathrm{Ph})$; $84.3(\mathrm{Cp}) ; 70.8\left(\mathrm{~d}, J_{\mathrm{C}-\mathrm{F}}=21.8 \mathrm{~Hz}, \mathrm{CH}_{2}\right) ; 55.4\left(\mathrm{CH}_{3}\right) .{ }^{31} \mathrm{P} \mathrm{NMR}-40$ ${ }^{\circ} \mathrm{C}, \mathrm{CDCl}_{3}: 50.2\left(\mathrm{~d}, J_{\mathrm{P}-\mathrm{F}}=47.0 \mathrm{~Hz}\right)$. MS FAB m/z: $858\left(\mathrm{M}^{+}\right), 839$ $\left(\mathrm{M}^{+}-\mathrm{F}\right), 794\left(\mathrm{M}^{+}-\mathrm{F}, \mathrm{CH}_{2} \mathrm{OMe}\right), 631\left(\mathrm{M}^{+}-\mathrm{C}_{2} \mathrm{FPhCH}_{2} \mathrm{OMe}\right)$, $431\left(\mathrm{M}^{+}-\mathrm{PPh}_{3}, \mathrm{C}_{2} \mathrm{FPhCH} \mathrm{H}_{2} \mathrm{OMe}\right)$. Only one of the $E, Z$-isomers was obtained and the spectroscopic data are not sufficient to identify the configuration. No reaction was observed when $\mathbf{2} \mathbf{j}$ was treated with $(n-\mathrm{Bu})_{4} \mathrm{NOH}$ or DBU.

Reaction of 3b with TCNQ. To a mixture of $\mathbf{3 b}(0.934 \mathrm{~g}, 1.12$ mmol) and TCNQ (0.234 g, $1.15 \mathrm{mmol})$ was added under nitrogen 20 $\mathrm{mL}$ of $\mathrm{CH}_{2} \mathrm{Cl}_{2}$. The solution was stirred at room temperature for 20 min and then the solvent was removed under vacuum. The residue was washed with $3 \times 20 \mathrm{~mL}$ of methanol to produce the light orange microcrystals identified as $[\mathrm{Ru}]=\mathrm{C}=\mathrm{C}(\mathrm{Ph}) \mathrm{CH}(\mathrm{CN}) \mathrm{TCNQ}(\mathbf{6 b})(1.04$ g, $1.01 \mathrm{mmol}, 90 \%$ yield). Spectroscopic data for $\mathbf{6 b}$ : ${ }^{1} \mathrm{H}$ NMR, $\mathrm{CDCl}_{3}$ : 7.50-6.77 (m, 39H, Ph); 5.24 (s, 5H, Cp); 3.32 (s, 1H, CH). ${ }^{13} \mathrm{C} \mathrm{NMR}_{\mathrm{CDCl}}: 336.8\left(\mathrm{t}, J_{\mathrm{P}-\mathrm{C}}=14.7 \mathrm{~Hz}, \mathrm{C}_{\alpha}\right) ; 146.2-119.4(\mathrm{Ph})$; 123.3, 123.0, 114.8, 113.9, 113.3, $111.4\left(5 \mathrm{CN}\right.$ and $\left.\mathrm{C}_{\beta}\right)$; $95.8(\mathrm{Cp})$; 45.1, $31.4\left(2 \mathrm{C}(\mathrm{CN})_{2}\right) ; 39.2(\mathrm{CHCN}) .{ }^{31} \mathrm{P} \mathrm{NMR}, \mathrm{CDCl}_{3}: 40.6,38.8$ (two d, $J_{\mathrm{P}-\mathrm{P}}=26.6 \mathrm{~Hz}$ ). MS FAB $\mathrm{m} / z: 1038\left(\mathrm{M}^{+}+1\right), 833\left(\mathrm{M}^{+}-\right.$ TCNQ), $571\left(\mathrm{M}^{+}-\mathrm{PPh}_{3}\right.$, TCNQ), $431\left(\mathrm{M}^{+}-\mathrm{PPh}_{3}\right.$, vinylidene). Anal. Calcd for $\mathrm{C}_{63} \mathrm{H}_{45} \mathrm{~N}_{5} \mathrm{P}_{2} \mathrm{Ru}:$ C, 73.10; H, 4.38; N, 6.77. Found: C, 73.23; $\mathrm{H}, 4.76$; N, 6.54 .

Synthesis of $[\mathrm{Ru}]=\mathrm{C}=\mathrm{C}(\mathrm{Ph}) \mathrm{CH}(\mathrm{TCNQ}) \mathrm{CO}_{2} \mathrm{Me}(6 \mathrm{~h})$. The procedure used for the synthesis of $\mathbf{6 h}$ is similar to that used for $\mathbf{6 b}$. The yield of the orange complex $\mathbf{6 h}(0.408 \mathrm{~g}, 0.382 \mathrm{mmol})$ from the reaction of $4 \mathrm{~h}(0.375 \mathrm{~g}, 0.434 \mathrm{mmol})$ and TCNQ $(0.090 \mathrm{~g}, 0.44 \mathrm{mmol})$ is $88 \%$. Spectroscopic data for $\mathbf{6 h}:{ }^{1} \mathrm{H}$ NMR $\mathrm{CDCl}_{3}: 7.46-6.84(\mathrm{~m}, 39 \mathrm{H}$, $\mathrm{Ph}) ; 5.09$ (s, 5H, Cp); $3.70\left(\mathrm{~s}, 4 \mathrm{H}, \mathrm{CO}_{2} \mathrm{CH}_{3}\right.$ and $\left.\mathrm{CH}\right) .{ }^{13} \mathrm{C}$ NMR $\mathrm{CDCl}_{3}: 340.1\left(\mathrm{t}, J_{\mathrm{P}-\mathrm{C}}=15.1 \mathrm{~Hz}, \mathrm{C}_{\alpha}\right) ; 168.1\left(\mathrm{CO}_{2} \mathrm{Me}\right) ; 145.6-119.3$ $(\mathrm{Ph}) ; 126.1,124.4,115.8,114.9,113.6\left(\mathrm{C}_{\beta}\right.$ and $\left.\mathrm{CN}\right) ; 95.6(\mathrm{Cp}) ; 53.0$ $\left(\mathrm{CO}_{2} \mathrm{CH}_{3}\right) ; 49.5$, 31.0 $\left(2 \mathrm{C}(\mathrm{CN})_{2}\right) ; 43.1 \quad\left(\mathrm{CHCO}_{2} \mathrm{Me}\right) .{ }^{31} \mathrm{P} \quad \mathrm{NMR}$ $\mathrm{CDCl}_{3}: 40.0,38.7$ (two $d, J_{\mathrm{P}-\mathrm{P}}=25.3 \mathrm{~Hz}$ ). MS FAB $m / z: 1071\left(\mathrm{M}^{+}\right.$ $+1), 866\left(\mathrm{M}^{+}-\mathrm{TCNQ}\right), 604\left(\mathrm{M}^{+}-\mathrm{TCNQ}, \mathrm{PPh}_{3}\right), 431\left(\mathrm{M}^{+}-\mathrm{PPh}_{3}\right.$, vinylidene). Anal. Calcd for $\mathrm{C}_{64} \mathrm{H}_{48} \mathrm{~N}_{4} \mathrm{O}_{2} \mathrm{P}_{2} \mathrm{Ru}$ : C, 71.97; $\mathrm{H}, 4.53 ; \mathrm{N}$, 5.25. Found: $\mathrm{C}, 72.11 ; \mathrm{H}, 4.39 ; \mathrm{N}, 5.42$.

Synthesis of $[\mathbf{R u}]=\mathbf{C}=\mathbf{C}(\mathbf{P h}) \mathbf{C H}=\mathbf{C H C H}_{2} \mathbf{T C N Q}$ (7d). To a mixture of $3 \mathbf{d}(0.241 \mathrm{~g}, 0.29 \mathrm{mmol})$ and TCNQ $(0.059 \mathrm{~g}, 0.29 \mathrm{mmol})$ at $-40{ }^{\circ} \mathrm{C}$ was added $10 \mathrm{~mL}$ of $\mathrm{CH}_{2} \mathrm{Cl}_{2}$. The solution was stirred at $-40{ }^{\circ} \mathrm{C}$ for $10 \mathrm{~min}$ and then the solvent was removed under vacuum. The residue was first washed with $2 \times 20 \mathrm{~mL}$ of methanol and then dried under vacuum to give the brown product identified as $\mathbf{7 d}(0.161$ g, $0.16 \mathrm{mmol}, 54 \%$ yield). Spectroscopic data for $7 \mathrm{~d}$ : ${ }^{1} \mathrm{H}$ NMR $\mathrm{CDCl}_{3}: 7.44-6.80(\mathrm{~m}, 39 \mathrm{H}, \mathrm{Ph}) ; 5.49\left(\mathrm{~d}, 1 \mathrm{H}, J_{\mathrm{H}-\mathrm{H}}=15.1 \mathrm{~Hz},=\mathrm{CH}\right)$; $5.11(\mathrm{~s}, 5 \mathrm{H}, \mathrm{Cp}) ; 4.61(\mathrm{~m}, 1 \mathrm{H},=\mathrm{CH}) ; 2.64\left(\mathrm{~d}, 2 \mathrm{H}, J_{\mathrm{H}-\mathrm{H}}=7.54 \mathrm{~Hz}\right.$,
$\left.\mathrm{CH}_{2}\right) .{ }^{13} \mathrm{C} \mathrm{NMR} \mathrm{CD}_{3} \mathrm{COCD}_{3}: 355.8\left(\mathrm{C}_{\alpha}\right) ; 144.6-128.7(\mathrm{Ph}) ; 124.3$, $118.0(2=\mathrm{CH}) ; 119.2,118.5(4 \mathrm{CN}) ; 95.1(\mathrm{Cp}) ; 46.4\left(\mathrm{CH}_{2}\right) ; 42.2$, $30.7\left(2 \mathrm{C}(\mathrm{CN})_{2}\right)$. ${ }^{31} \mathrm{P} \mathrm{NMR} \mathrm{CDCl} l_{3}: 41.2$. MS FAB $m / z: 1039\left(\mathrm{M}^{+}\right)$, $835\left(\mathrm{M}^{+}-\mathrm{TCNQ}\right), 777\left(\mathrm{M}^{+}-\mathrm{PPh}_{3}\right), 571\left(\mathrm{M}^{+}-\mathrm{TCNQ}, \mathrm{PPh}_{3}\right)$. Anal. Calcd for $\mathrm{C}_{64} \mathrm{H}_{48} \mathrm{~N}_{4} \mathrm{P}_{2} \mathrm{Ru}$ : C, 74.19; H, 4.67; N, 5.41. Found: C, 74.35; H, 4.89; N, 5.63.

Reaction of $6 \mathrm{~b}$ with $\mathrm{MeOH} / \boldsymbol{n}-\mathrm{Bu}_{4} \mathrm{NOH}$. To a solution of $6 \mathrm{~b}(0.506$ $\mathrm{g}, 0.48 \mathrm{mmol}$ in $10 \mathrm{~mL}$ of acetone) was added $2.5 \mathrm{~mL}$ of $\mathrm{CH}_{3} \mathrm{OH} /(n$ $\mathrm{Bu})_{4} \mathrm{NOH}$. The color of the solution immediately changed to darkgreen with the formation of light yellow precipitate. The solution was further stirred at room temperature for $40 \mathrm{~min}$ and then was filtered. The precipitate was washed with $3 \times 20 \mathrm{~mL}$ of methanol to give the yellow product. Recrystallization from a mixture of $1: 1 \mathrm{CH}_{2} \mathrm{Cl}_{2} / \mathrm{CH}_{3}$ $\mathrm{CN}$ gave $[\mathrm{Ru}]-\mathrm{C}=\mathrm{C}(\mathrm{Ph}) \mathrm{C}(\mathrm{CN}) \mathrm{OMe}(\mathbf{9 b})(0.366 \mathrm{~g}, 0.43 \mathrm{mmol}, 88 \%$ yield). Spectroscopic data for 9b: ${ }^{1} \mathrm{H} \mathrm{NMR}, \mathrm{CDCl}_{3}$ : $7.25-6.64(\mathrm{~m}$, $35 \mathrm{H}, \mathrm{Ph}$ ); 4.66 (s, 5H, Cp); 3.44 (s, 3H, Me). ${ }^{13} \mathrm{C}$ NMR, $\mathrm{CDCl}_{3}: 136.2$ $\left(\mathrm{t}, J_{\mathrm{P}-\mathrm{C}}=19.8 \mathrm{~Hz}, \mathrm{C}_{\alpha}\right) ; 139.7-127.4(\mathrm{Ph}) ; 109.4(\mathrm{CN}) ; 86.3(\mathrm{Cp})$; $59.3(C(\mathrm{CN})(\mathrm{OMe})) ; 55.8(\mathrm{OMe}) .{ }^{31} \mathrm{P} \mathrm{NMR}, \mathrm{CDCl}_{3}: 51.7,4.96$ (two $\left.\mathrm{d}, J_{\mathrm{P}-\mathrm{P}}=36.0 \mathrm{~Hz}\right)$. MS FAB $m / z: 863\left(\mathrm{M}^{+}\right), 848\left(\mathrm{M}^{+}-\mathrm{Me}\right), 832$ $\left(\mathrm{M}^{+}-\mathrm{OMe}\right), 693\left(\mathrm{M}^{+}-\right.$cyclopropenyl moiety), $601\left(\mathrm{M}^{+}-\mathrm{PPh}_{3}\right)$, $431\left(\mathrm{M}^{+}-\mathrm{PPh}_{3}\right.$, cyclopropenyl moiety). Anal. Calcd for $\mathrm{C}_{52} \mathrm{H}_{43^{-}}$ $\mathrm{NOP}_{2} \mathrm{Ru}: \mathrm{C}, 72.54 ; \mathrm{H}, 5.03 ; \mathrm{N}, 1.63$. Found: $\mathrm{C}, 73.07 ; \mathrm{H}, 5.06 ; \mathrm{N}$, 1.56 .

Reaction of $9 \mathrm{~b}$ with $\mathbf{C F}_{3} \mathbf{C O O H}$. To a solution of $\mathbf{9 b}(0.078 \mathrm{~g}$, $0.091 \mathrm{mmol}$ in $2 \mathrm{~mL}$ of $\mathrm{CH}_{2} \mathrm{Cl}_{2}$ ) was added $2.5 \mu \mathrm{L}$ of $\mathrm{CF}_{3} \mathrm{COOH}$. The color of the solution immediately changed from yellow to amber-red. The solution was stirred at room temperature for $20 \mathrm{~min}$ and then 30 $\mathrm{mL}$ of hexane was added. The orange precipitate thus formed was filtered and then washed with $2 \times 5 \mathrm{~mL}$ of hexane to give the product identified as $[[\mathrm{Ru}]-\mathrm{CC}(\mathrm{Ph}) \mathrm{C}(\mathrm{CN})]\left[\mathrm{CF}_{3} \mathrm{COO}\right](\mathbf{1 0 b})(0.067 \mathrm{~g}, 0.071$ mmol, $78 \%$ yield). Spectroscopic data for $\mathbf{1 0 b}$ : ${ }^{1} \mathrm{H}$ NMR, $\mathrm{CDCl}_{3}$ : 8.15-6.91 (m, 35H, Ph); 4.91 (s, 5H, Cp). ${ }^{13} \mathrm{C} \mathrm{NMR,} \mathrm{CDCl}_{3}: 213.0$ $\left(\mathrm{t}, J_{\mathrm{P}-\mathrm{C}}=17.2 \mathrm{~Hz}, \mathrm{C}_{\alpha}\right) ; 183.1(C(\mathrm{CN})) ; 162.2\left(\mathrm{q}, J_{\mathrm{C}-\mathrm{F}}=43.0 \mathrm{~Hz}\right.$, $\mathrm{CO}) ; 138.0-127.6(\mathrm{Ph}) ; 121.6(\mathrm{CN}) ; 114.3\left(\mathrm{q}, J_{\mathrm{C}-\mathrm{F}}=282.0 \mathrm{~Hz}, \mathrm{CF}_{3}\right)$; $107.9(\mathrm{CPh}), 90.1(\mathrm{Cp}) .{ }^{31} \mathrm{P} \mathrm{NMR}, \mathrm{CDCl}_{3}: 46.8(\mathrm{~s})$. MS FAB $\mathrm{m} / \mathrm{z}$ : $848\left(\mathrm{M}^{+}+\mathrm{O}-\mathrm{CF}_{3} \mathrm{COO}\right), 832\left(\mathrm{M}^{+}\right), 693\left(\mathrm{M}^{+}-\right.$cyclopropenylium), $431\left(\mathrm{M}^{+}-\mathrm{PPh}_{3}\right.$, cyclopropenylium). Anal. Calcd for $\mathrm{C}_{53} \mathrm{H}_{40^{-}}$ $\mathrm{F}_{3} \mathrm{NO}_{2} \mathrm{P}_{2} \mathrm{Ru}$ : $\mathrm{C}, 67.51 ; \mathrm{H}, 4.28 ; \mathrm{N}, 1.49$. Found: $\mathrm{C}, 67.44 ; \mathrm{H}, 4.45$; N, 1.60. Complex $\mathbf{1 0 b}$ is ether sensitive.

Synthesis of $[\mathrm{Ru}]-\mathrm{C}=\mathrm{C}(\mathrm{Ph}) \mathrm{C}(\mathrm{OMe}) \mathrm{CO}_{2} \mathrm{Me}(9 \mathrm{~h})$. To a suspension of $\mathbf{6 h}(0.210 \mathrm{~g}, 0.197 \mathrm{mmol})$ in $10 \mathrm{~mL}$ of acetone was added $(n-$ $\mathrm{Bu})_{4} \mathrm{NOH}(1.0 \mathrm{~mL})$ and the color turned to yellow immediately. The solution was stirred at room temperature for $30 \mathrm{~min}$. Unlike reactions leading to cyclopropenyl complexes, this one did not yield any precipitate. The solvent was thus removed under vacuum, the residue was extracted with $2 \times 15 \mathrm{~mL}$ of hexane, then the solution was dried under vacuum to give $9 \mathrm{~h}(0.105 \mathrm{~g}, 60 \%$ yield $)$. Spectroscopic data for 9h: ${ }^{1} \mathrm{H} \mathrm{NMR} \mathrm{CDCl} \mathrm{N}_{3}$ : 7.50-6.22 (m, $\left.35 \mathrm{H}, \mathrm{Ph}\right) ; 4.56$ (s, 5H, Cp); $3.63\left(\mathrm{~s}, 3 \mathrm{H}, \mathrm{CO}_{2} \mathrm{CH}_{3}\right) ; 3.29$ (s, $\left.3 \mathrm{H}, \mathrm{OCH}_{3}\right)$. ${ }^{13} \mathrm{C} \mathrm{NMR} \mathrm{CDCl}_{3}: 179.7$ (s, COO); 140.9-125.2 (Ph); $85.8(\mathrm{Cp}) ; 55.3(\mathrm{OMe}) ; 53.9\left(\mathrm{C}_{\beta} \mathrm{sp}^{3}\right)$; $51.2\left(\mathrm{CO}_{2} \mathrm{CH}_{3}\right)$. ${ }^{31} \mathrm{P} \mathrm{NMR} \mathrm{CDCl}{ }_{3}: 53.6\left(\mathrm{~d}, J_{\mathrm{P}-\mathrm{P}}=34.8 \mathrm{~Hz}\right), 48.0(\mathrm{~d}$, $\left.J_{\mathrm{P}-\mathrm{P}}=34.8 \mathrm{~Hz}\right)$. MS FAB $m / z: 896\left(\mathrm{M}^{+}\right), 880\left(\mathrm{M}^{+}-\mathrm{O}\right), 693\left(\mathrm{M}^{+}\right.$ - cyclopropenyl moiety), $633\left(\mathrm{M}^{+}-\mathrm{PPh}_{3}\right)$.

Synthesis of $\left[[\mathrm{Ru}]-\mathbf{C C}(\mathrm{Ph}) \mathbf{C C O} \mathbf{C O}_{2} \mathrm{Me}\right]\left[\mathrm{CF}_{3} \mathrm{COO}\right](\mathbf{1 0 h})$. Complex 9h $(0.210 \mathrm{~g}, 0.197 \mathrm{mmol})$ was dissolved in $20 \mathrm{~mL}$ of $\mathrm{CHCl}_{3}$ and excess $\mathrm{CF}_{3} \mathrm{COOH}$ was added. The color of the solution changed from yellow to orange. After $1 \mathrm{~h}$, the solvent was removed under vacuum and the residue was washed with $2 \times 20 \mathrm{~mL}$ of hexane to yield the orange product 10h $(0.209 \mathrm{~g}, 92 \%)$. Spectroscopic data for $\mathbf{1 0 h}:{ }^{1} \mathrm{H}$ NMR $\mathrm{CDCl}_{3}$ : 7.91-6.91 (m, 35 H, Ph); $4.75(\mathrm{~s}, 5 \mathrm{H}, \mathrm{Cp}) ; 3.80\left(\mathrm{~s}, 3 \mathrm{H}, \mathrm{CO}_{2-}\right.$ $\mathrm{Me}) .{ }^{13} \mathrm{C} \mathrm{NMR} \mathrm{CDCl}_{3}$ : $213.6\left(\mathrm{br}, \mathrm{C}_{\alpha}\right) ; 182.4,175.6(\mathrm{COO}$ and CCOO); $135.0-118.2(\mathrm{Ph}) ; 112.5\left(C_{\beta} \mathrm{Ph}\right) ; 89.3(\mathrm{Cp}) ; 53.8\left(\mathrm{CH}_{3}\right) .{ }^{31} \mathrm{P}$ NMR CDCl 3 : 47.6. MS FAB m/z: $881\left(\mathrm{M}^{+}+\mathrm{O}\right), 865\left(\mathrm{M}^{+}\right), 693$ $\left(\mathrm{M}^{+}-\right.$cyclopropenyl moiety). Anal. Calcd for $\mathrm{C}_{54} \mathrm{H}_{43} \mathrm{~F}_{3} \mathrm{O}_{4} \mathrm{P}_{2} \mathrm{Ru}: \mathrm{C}$, 66.46; H, 4.44. Found: C, 66.28; H, 4.32.

Reaction of 10b with MeONa in THF. To a solution of $10 \mathrm{~b}(0.016$ g, $0.017 \mathrm{mmol}$ in $2 \mathrm{~mL}$ THF) was added a small amount of $\mathrm{CH}_{3} \mathrm{ONa}$ $(0.005 \mathrm{~g})$. The solution was stirred at room temperature for $30 \mathrm{~min}$ and then the solvent was removed under vacuum. The residue was extracted with $\mathrm{CHCl}_{3}$ and solvent removed under vacuum to give $[\mathrm{Ru}]-$ 
$\mathrm{C}(\mathrm{OMe}) \mathrm{C}(\mathrm{Ph})=\mathrm{C}(\mathrm{CN}) \quad(\mathbf{8 b}) \quad(0.013 \mathrm{~g}, 0.015 \mathrm{mmol}, \quad 88 \%$ yield $)$. Spectroscopic data for $\mathbf{8 b}:{ }^{1} \mathrm{H} \mathrm{NMR}, \mathrm{CDCl}_{3}: 7.28-6.63(\mathrm{~m}, 35 \mathrm{H}, \mathrm{Ph})$; 4.50 (s, 5H, Cp); 3.29 (s, 3H, Me). ${ }^{31} \mathrm{P} \mathrm{NMR}, \mathrm{CDCl}_{3}$ : 51.2, 50.7 (two $\mathrm{d}, J_{\mathrm{P}-\mathrm{P}}=29.6 \mathrm{~Hz}$ ). Complex $\mathbf{8 b}$ in acetone is unstable and readily converts to $9 \mathbf{b}$ quantitatively, but is stable in THF and $\mathrm{CHCl}_{3}$.

Synthesis of $[\mathbf{R u}]-\mathbf{C}=\mathbf{C}(\mathbf{P h}) \mathbf{C}(\mathbf{C N})_{2}$ (3m). Complex $\mathbf{6 b}(0.250$ $\mathrm{g}, 0.24 \mathrm{mmol}$ ) was dissolved in $10 \mathrm{~mL}$ of acetone and a solution of $(n \text {-Bu })_{4} \mathrm{NCN}(0.201 \mathrm{~g}$ in $5 \mathrm{~mL}$ of $\mathrm{MeOH})$ was added at room temperature. The solution was stirred for $2 \mathrm{~h}$ and the yellow precipitate thus formed was filtered and washed with $2 \times 10 \mathrm{~mL}$ of $\mathrm{MeOH}$ to give the product $\mathbf{3 m}$. Spectroscopic data for $\mathbf{3 m}$ : ${ }^{1} \mathrm{H}$ NMR $\mathrm{CDCl}_{3}$ : 7.23-6.60 (m, $35 \mathrm{H}, \mathrm{Ph}) ; 4.75$ (s, $5 \mathrm{H}, \mathrm{Cp}) .{ }^{13} \mathrm{C} \mathrm{NMR} \mathrm{CDCl}_{3}$ : $138.9-$ $126.8(\mathrm{Ph}) ; 123.2(\mathrm{CN}) ; 86.7(\mathrm{Cp}) ; 7.89\left(C(\mathrm{CN})_{2}\right)$. ${ }^{31} \mathrm{P} \mathrm{NMR} \mathrm{CDCl}_{3}$ : 48.3. MS FAB m/z: $859\left(\mathrm{M}^{+}\right), 693\left(\mathrm{M}^{+}-\mathrm{C}_{2} \mathrm{PhC}(\mathrm{CN})_{2}\right), 596\left(\mathrm{M}^{+}-\right.$ $\mathrm{PPh}_{3}$ ). Anal. Calcd for $\mathrm{C}_{52} \mathrm{H}_{40} \mathrm{~N}_{2} \mathrm{P}_{2} \mathrm{Ru}: \mathrm{C}, 72.97 ; \mathrm{H}, 4.71 ; \mathrm{N}, 3.27$. Found: C, 73.15; H, 4.89; N, 3.46 .

Synthesis of $\left[[\mathrm{Ru}]=\mathbf{C}=\mathbf{C}(\mathrm{Ph}) \mathbf{C}(\mathrm{CN})_{2} \mathrm{H}\right]\left[\mathrm{CF}_{3} \mathrm{COO}\right](2 \mathrm{~m})$. Complex $3 \mathbf{m}(0.080 \mathrm{~g}, 0.093 \mathrm{mmol})$ was dissolved in $0.5 \mathrm{~mL}$ of $\mathrm{CDCl}_{3}$ and $\mathrm{CF}_{3} \mathrm{COOH}(0.03 \mathrm{~mL})$ was added. The solvent was removed under vacuum and the product washed with hexane was identified as $\mathbf{2 m}$. Spectroscopic data for $2 \mathrm{~m}$ : ${ }^{1} \mathrm{H}$ NMR $\mathrm{CDCl}_{3}$ : 7.52-6.85 (m, $35 \mathrm{H}$, $\mathrm{Ph}) ; 5.25$ (s, 5H, Cp); 4.08 (s, $\left.1 \mathrm{H}, \mathrm{C}(\mathrm{CN})_{2} \mathrm{H}\right) .{ }^{13} \mathrm{C} \mathrm{NMR} \mathrm{CDCl}_{3}: 336.3$ (br, $\left.\mathrm{C}_{\alpha}\right) ; 162.2\left(\mathrm{q}, J_{\mathrm{F}-\mathrm{C}}=43.0 \mathrm{~Hz}, \mathrm{CF}_{3} \mathrm{COO}\right) ; 135.8-121.5(\mathrm{Ph}) ; 121.0$ $\left(\mathrm{C}_{\beta}\right) ; 118.6(\mathrm{CN}) ; 114.3\left(\mathrm{q}, J_{\mathrm{F}-\mathrm{C}}=282.0 \mathrm{~Hz}, \mathrm{CF}_{3}\right) ; 96.2(\mathrm{Cp}) ; 19.7$ $\left(C(\mathrm{CN})_{2}\right) .{ }^{31} \mathrm{P} \mathrm{NMR} \mathrm{CDCl} \mathrm{Cl}_{3}:$ 39.4. MS FAB $\mathrm{m} / \mathrm{z}: 859\left(\mathrm{M}^{+}\right), 693\left(\mathrm{M}^{+}\right.$ $\left.-\mathrm{C}_{2} \mathrm{PhC}_{3} \mathrm{~N}_{2} \mathrm{H}\right), 596\left(\mathrm{M}^{+}-\mathrm{PPh}_{3}\right)$. Anal. Calcd for $\mathrm{C}_{54} \mathrm{H}_{41^{-}}$ $\mathrm{F}_{3} \mathrm{~N}_{2} \mathrm{O}_{2} \mathrm{P}_{2} \mathrm{Ru}$ : C, 66.87; H, 4.26; N, 2.89. Found: $\mathrm{C}, 66.59 ; \mathrm{H}, 3.97$; $\mathrm{N}, 2.96$. Complex $\mathbf{2 m}$ was converted back to $\mathbf{3 m}$ by $(n-\mathrm{Bu})_{4} \mathrm{NOH} /$ $\mathrm{MeOH}$ solution in quantitative NMR yield.

Dimerization of $\mathbf{3 b}$ in the Presence of Allyl Iodide. Excess freshly distilled allyl iodide $(0.65 \mathrm{~mL}, 7.1 \mathrm{mmol})$ was added to a solution of 3b $(0.31 \mathrm{~g}, 0.37 \mathrm{mmol})$ in $10 \mathrm{~mL}$ of $\mathrm{CHCl}_{3}$. This mixture was stirred at room temperature for $48 \mathrm{~h}$ to give orange red precipitate which was filtered off, washed with $20 \mathrm{~mL}$ of $\mathrm{CHCl}_{3}$ and $2 \times 10 \mathrm{~mL}$ of hexane, then dried in vacuo yielding $[[\mathrm{Ru}]=\mathrm{C}=\mathrm{C}(\mathrm{Ph}) \mathrm{CH}(\mathrm{CN})]_{2} \mathrm{I}_{6}$ (11) $(0.44$ $\mathrm{g}, 0.18 \mathrm{mmol}, 49 \%$ yield). 11 is insoluble in common organic solvents except DMSO. Spectroscopic data for 11: ${ }^{1} \mathrm{H}$ NMR $d_{6}$-DMSO: 7.576.59 (m, 70H, Ph); 5.34 (s, 10H, Cp); 3.51 (s, 2H, CH). ${ }^{13} \mathrm{C}$ NMR $d_{6}$-DMSO: $354.3\left(\mathrm{t}, \mathrm{C}_{\alpha}\right)$; 132.9-123.2 (Ph); $120.7\left(\mathrm{C}_{\beta}\right) ; 116.5(\mathrm{CN})$; 95.6 (Cp); $32.5(\mathrm{CH}) .{ }^{31} \mathrm{P}$ NMR $d_{6}$-DMSO: $42.3,41.3\left(\mathrm{~d}, J_{\mathrm{P}-\mathrm{P}}=26.7\right.$ Hz). MS FAB m/z: $1792\left(\mathrm{M}^{+}+\mathrm{I}\right), 1531\left(\mathrm{M}^{+}+1-\mathrm{PPh}_{3}\right), 1271$ $\left(\mathrm{M}^{+}+1-2 \mathrm{PPh}_{3}\right), 1142\left(\mathrm{M}^{+}-2 \mathrm{PPh}_{3}\right)$. Anal. Calcd for $\mathrm{C}_{102} \mathrm{H}_{82} \mathrm{~N}_{2} \mathrm{P}_{4^{-}}$ $\mathrm{Ru}_{2} \mathrm{I}_{6}$ ( $\mathrm{I}_{6}$ salt from recrystallization): C, 50.55; H, 3.41; N, 1.15 . Found: C, 51.01; H, 3.11; N, 1.42.

Proton Abstraction of 11. To a suspension of $11(0.15 \mathrm{~g}, .062$ $\mathrm{mmol})$ in $5 \mathrm{~mL}$ of acetone was added $(n-\mathrm{Bu})_{4} \mathrm{NOH}(1.0 \mathrm{~mL})$ and yellow precipitate formed immediately. The precipitate was filtered and washed with $2 \times 5 \mathrm{~mL}$ of acetone then dried under vacuum. This

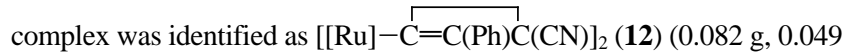
mmol, $80 \%$ yield) based on its spectroscopic data and mass spectrum. Spectroscopic data for 12: ${ }^{1} \mathrm{H} \mathrm{NMR} \mathrm{CDCl}_{3}$ : 7.47-6.40 (m, 70H, Ph);

(57) Gabe, E. J.; Lee, F. L.; Lepage, Y. In Crystallographic Computing 3; Sheldrick, G. M., Kruger, C., Goddard, R., Eds.; Clarendon Press: Oxford, England, 1985; p 167.

(58) International Tables for X-ray Crystallography; Reidel Publishing Co.: Dordrecht, Boston, 1974; Vol. IV.
4.87 (s, 10H, Cp). ${ }^{13} \mathrm{C} \mathrm{NMR} \mathrm{CDCl}_{3}: 140.1-126.2(\mathrm{Ph}) ; 124.6(\mathrm{CN})$; $85.6(\mathrm{Cp}) ; 30.4(C \mathrm{CN}) .{ }^{31} \mathrm{P} \mathrm{NMR} \mathrm{CDCl} \mathrm{NM}_{3}: 49.7,48.5\left(\mathrm{~d}, J_{\mathrm{P}-\mathrm{P}}=36.4\right.$ Hz). MS FAB, m/e: $1665\left(\mathrm{M}^{+}\right), 1402\left(\mathrm{M}^{+}-\mathrm{PPh}_{3}\right), 1140\left(\mathrm{M}^{+}-\right.$ $2 \mathrm{PPh}_{3}$ ). Anal. Calcd for $\mathrm{C}_{102} \mathrm{H}_{80} \mathrm{~N}_{2} \mathrm{P}_{4} \mathrm{Ru}_{2}$ : C, 73.81; H, 4.86; N, 1.69. Found: C, 73.52; H, 4.72; N, 1.83 .

X-ray Analysis of 3b, 3f, $4 \mathrm{~h}, \mathbf{6 b}, \mathbf{9 b}$, and 11. Single crystals of 3b suitable for an X-ray diffraction study were grown as mentioned above. A single crystal of dimensions $0.40 \times 0.40 \times 0.45 \mathrm{~mm}^{3}$ was glued to a glass fiber and mounted on an Enraf-Nonius CAD4 diffractometer. Initial lattice parameters were determined from a leastsquares fit to 25 accurately centered reflections with $10.0^{\circ}<2 \theta<$ $25^{\circ}$. Cell constants and other pertinent data are collected in the supporting information. Data were collected using the $\theta / 2 \theta$ scan method. The final scan speed for each reflection was determined from the net intensity gathered during an initial prescan and ranged from 2 to $7 \mathrm{deg} \mathrm{min}^{-1}$. The scan angle was determined for each reflection according to the equation $0.8+0.35 \tan \theta$.

The raw intensity data were converted to structure factor amplitudes and their esd's by correction for scan speed, background, and Lorentz, polarization effects. An empirical correction for absorption based on the azimuthal scan was applied to the data set. Crystallographic computations were carried out on a Microvax III computer using the NRCC structure determination package. ${ }^{57}$ Merging of equivalent and duplicate reflections gave a total of 5194 unique measured data from which 4106 were considered observed, $I>2.0 \sigma(I)$. The structure was first solved by using the heavy atom method (Patterson synthesis) which revealed the position of metal, then refined via standard least-squares and difference Fourier techniques. The quantity minimized by the leastsquares program was $w\left(\left[F_{\mathrm{o}}|-| F_{\mathrm{c}} \mid\right)^{2}\right.$. The analytical forms of the scattering factor tables for the neutral atoms were used. ${ }^{58}$ All other non-hydrogen atoms were refined by using anisotropic thermal parameters. Hydrogen atoms were included in the structure factor calculations in their expected positions on the basis of idealized bonding geometry but were not refined in least squares. Final refinement using full-matrix, least-squares converged smoothly to values of $R=0.040$ and $R_{\mathrm{w}}=0.034$. Final values of all refined atomic positional parameters (with esd's) and tables of thermal parameters are given in the supporting information.

The procedures for $\mathbf{3 f}, \mathbf{4 h}, \mathbf{6 b}, \mathbf{9 b}$, and $\mathbf{1 1}$ were similar. The final residuls of the refinement were $R=0.070, R_{\mathrm{w}}=0.066$ for $\mathbf{3 f} ; R=$ $0.061, R_{\mathrm{W}}=0.068$ for $4 \mathbf{h} ; R=0.073, R_{\mathrm{W}}=0.075$ for $\mathbf{6 b} ; R=0.033$, $R_{\mathrm{w}}=0.034$ for $9 \mathrm{~b}$; and $R=0.062, R_{\mathrm{w}}=0.042$ for 11 . Final values of all refined atomic positional parameters (with esd's) and tables of thermal parameters are given in the supporting information.

Acknowledgment. We are grateful for support of this work by the National Science Council, Taiwan, Republic of China.

Supporting Information Available: Details of the structural determination for complexes $3 \mathbf{b}, \mathbf{3 f}, \mathbf{4 h}, \mathbf{6 b}, \mathbf{9 b}$, and $\mathbf{1 1}$ including tables of crystal data and structure refinement, positional and anisotropic thermal parameters, and listings of bond distances and angles (49 pages). See any current masthead page for ordering and Internet access instructions.

JA960001K 